DOI: 10.30842/ielcp230690152473

\author{
A. V. Lebedev \\ (RAS Institute of philosophy)
}

\title{
A STUDY OF CONCEPTUAL METAPHOR IN HERACLITUS: METAPHORICAL CODES AND MODELS OF THE COSMOS IN HERACLITUS
}

First systematic study of Heraclitus' metaphorical language with a detailed typology of metaphorical codes (sets of related metaphors) and explanation of the meaning and interrelation of key conceptual metaphors that provides a clue for the understanding of the fundamental philosophical doctrines of Heraclitus including philosophy of nature, epistemology, philosophy of language. metaphysics, philosophical theology, anthropology, psychology, ethics and politics, as well philosophy of technology. The general introduction describes the peculiar features of philosophical metaphor by emphasizing its cognitive and explicative function (as opposed to the primarily aesthetic and expressive function of a poetic metaphor) and introduces an important typological distinction between a natural and metaphorical analogy. The following metaphorical codes and corresponding models of the cosmos are analyzed: mantic metaphorical code (the cosmos as an oracle), agonistic model (the cosmos as a stadium), military model (the cosmos as a battlefield), economic model (the cosmos as a household), game model (analogies from gameboard pesseia), sacral model (the cosmos as a temple), biomorphic metaphorical code (the cosmos as a living organism), technomorphic analogies (metallurgy, pottery etc.), sociomorphic model (Cosmopolis or the City of Zeus), hebdomadism (number seven in man and cosmos) in Heraclitus philosophy of nature.

Kev words: ancient philosophy, Early Greek philosophy, Heraclitus, conceptual metaphor, cognitive metaphor, metaphor in philosophy, analogy.

\author{
А. В. Лебедев \\ (Институт философии РАН)
}

\section{Концептуальная метафора у Гераклита: метафорические коды и модели космоса}

В статье предложено первое систематическое исследование метафорического языка Гераклита с детальной типологией метафорических кодов (групп или цепочек родственных метафор) и объяснением значения и взаимосвязи ключевых концептуальных метафор, которое дает ключ к пониманию фундаментальных философских доктрин Гераклита, включая философию природы, теорию познания, метафизику, философскую теологию, антропологию, психологию, этику и политику, а также философию техники и спорта. Анализируются следующие метафорические коды и соответствующие им модели космоса: мантический метафорический код (космос как оракул), агональ- 
ная модель (космос как стадион), военная модель (космос как поле битвы), экономическая модель (космос как хозяйство), игровая модель (метафоры из игры в пессейю), сакральная модель (космос как храм), биоморфная модель (космос как живой организм), техноморфная модель (металлургия, гончарное дело и т. д.), социоморфная модель (Космополис или Град Зевса), гебдомадизм (число семь в космосе и человеке).

Ключевые слова: античная философия, ранняя греческая философия, Гераклит, концептуальная метафора, когнитивная метафора, метафора в философии, аналогия.

\section{Models of the cosmos, analogies and metaphorical codes: general introduction ${ }^{1}$}

In the formative period of Greek philosophy and science when a stable and generally accepted terminology had not yet been developed, conceptual or cognitive metaphor and analogy played an important role $^{2}$. A philosophical metaphor differs from a poetic one in two respects: 1) it has a cognitive and explicative rather than (only) aesthetic and expressive function, 2) the philosophical conceptual metaphor is often not isolated, but is a part of a metaphorical code. A metaphorical code is a family or system of metaphors, a kind of "language game", which serves to describe a specific model of the cosmos in terms of one particular techne. The classical triad of Greek analogical cosmic models, which we will call biomorphic, technomorphic and sociomorphic, has been described in a pioneering and unjustly underestimated work of G. E. R. Lloyd (Lloyd 1966 who does not use these particular terms). As a matter of fact, technomorphic models - understanding techne in the Greek broad sense, including all the arts, crafts, and specialized practices - are as many as there "arts" and crafts ( $\tau \dot{\varepsilon} \chi v \alpha \imath)$ of the Greeks. Lloyd was not aware of the agonistic model of the cosmos of Heraclitus (first described in Lebedev 1985), as well as the economic ("lend-and-borrow") model of cosmic change in Anaximan-

\footnotetext{
${ }^{1}$ This is a revised and expanded English translation of the text originally published in Russian in Lebedev (2014), chapter 4. Section (2) on grammatical logos and alphabet analogy has been omitted as it has been superceded by a substantially expanded and revised English version published separately (Lebedev 2017). It should be taken into account as important integral part of the present study since it presents one the most important examples of the 'triadiac structure' $(2+1)$ which underlies most of the metaphorical codes and models of the cosmos discussed below.

${ }^{2}$ For metaphor and analogy in early Greek philosophy and science, see first of all Lloyd (1966) and the chapter "Metaphor and Language of Science" in Lloyd 1987 (172-214).
} 
der and Heraclitus, which serves to formulate the law of conservation of matter (Anaximander B 1 DK, Heraclitus 45Leb/B 31, $31 \mathrm{Leb} / \mathrm{B} 80,42 \mathrm{Leb} / \mathrm{B} 90)$. We believe that it is necessary to distinguish between a metaphorical analogy and a natural analogy. A metaphorical analogy can be "curtailed" into a metaphor; it has a certain resemblance to a poetic metaphor. A natural analogy differs from a metaphorical one in that — using the Lakoff-Johnson terminology (Lakoff, Johnson 1980) - its source domain and target domain do not differ, but coincide. For example, a comparison of the cosmos with a stadium, of opposites with runners, of the sun with an arbiter in Heraclitus (55Leb/B120, 56Leb [not in DK], $57 \mathrm{Leb} / \mathrm{B} 100)$ is a typical metaphorical analogy, since the description model is taken from the source domain of culture and transferred to the target domain of nature. An example of a natural analogy is the basic cosmogonic mechanism in the Ionian evolutionary history of cosmos: the cosmogonic "vortex" ( $\left.\delta^{i} v \eta\right)$. This concept is not poetic, but scientific: it is based on the observation of vortex movements in nature (for example, whirlwinds), which serve as an empirical

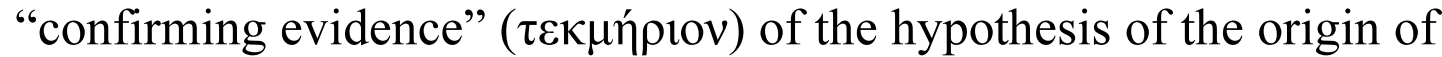
our world from a similar "large" vortex, in which heavy bodies also agglomerate in the center, and light ones are "pushed" or "squeezed" to the periphery. A natural analogy is also the comparison of the motion of atoms with the motion of dust particles in the sunbeam of Democritus (Aristotle. De anima, 404 a3). We call this type of analogy natural, since the modeling paradigm of explanation is taken from the observation of nature itself. A natural analogy appeared in Greek thought only thanks to the scientific revolution that took place in the 6th century BCE. in Miletus, when Thales, Anaximander and Anaximenes created the first naturalistic picture of the world in the intellectual history of mankind, replacing the complex theological apparatus of mythopoetic cosmogonies with only one wonder-word pviois 'nature'.

Heraclitus was a staunch opponent of this new, naturalistic and mechanistic, view of the world, since he perceived it as a threat to religion and morality. In his polemic with the Milesians, he for the first time employed the cosmological argument in favor of the

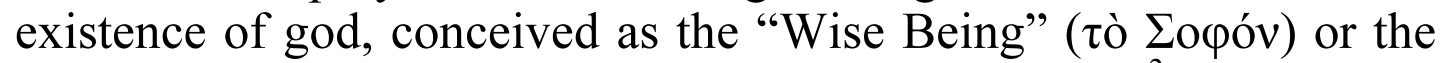
divine Mind (Гvต́ $\mu \eta)$, "governing the entire Universe" "3. If the world

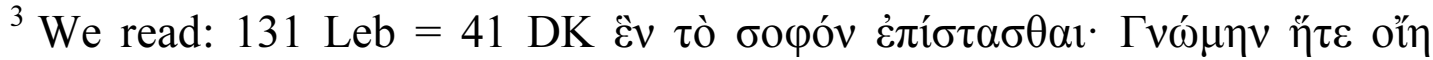

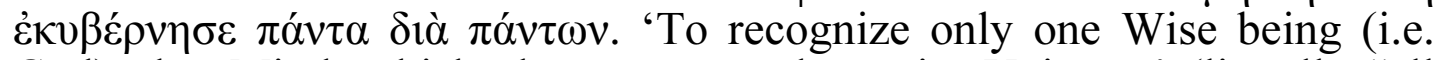
God): that Mind, which alone governs the entire Universe' (literally 'all
} 
arose from a spontaneous vortex, and not according to the divine plan (or planning mind, $\gamma v \omega ́ \mu \eta$ ), says Heraclitus, we would now

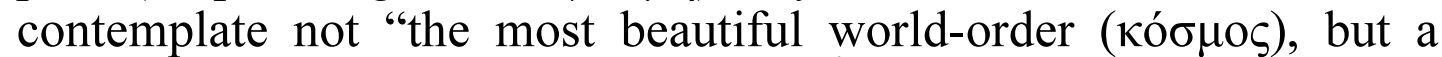
bunch of garbage scattered randomly". This is the earliest attestation of one of the greatest debates in the history of Western thought, the debate between evolutionism and creationism, between naturalistic determinism and teleology. It is remarkable that 2500 years ago Heraclitus anticipated Fred Hoyle's "junkyard tornado argument", although Hoyle himself intended it only as argument against abiogenesis and not as a creationist argument against Big Bang and Darwinian evolution used by modern proponents of the "intelligent design" theory. Incidentally, Heraclitus' $\gamma \nu \omega ́ \mu \eta$ combines the basic meaning of "intelligence" or "mind" (standard in Hippocratic corpus and early Ionian prose) with a connotation of "plan" which comes close to "design". The comparison of Heraclitus' polemics against Milesian vortex-cosmogony with modern "junkyard tornado" argument and "intelligent design" requires some reservations. Heraclitus does not speak about Boeing 747 created by chance by a tornado passing over a junkyard, he speaks about "most

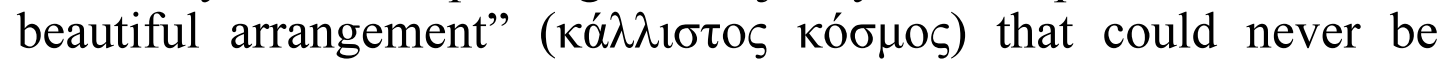
produced by a destructive whirlwind. Heraclitus rejected not only Ionian mechanistic naturalism, but also Pythagorean metaphysical substance dualism. Genuine theistic creationism is based on the substance dualism of god and matter, which is denied by Heraclitus' pantheism, by his identification of god and nature (physis). The Pythagorean and Platonic concept of demiourgos is inextricably linked with substance dualism. Heraclitus' creative cosmic mind is not "separated" from nature (which is not a passive matter-material of the Western Greek metaphysics!), but inherent and immanent in the fiery energy of pyr aeizoon, the remainder of which is Apollo the Sun. So, if Heraclitus was a creationist, he was a pantheistic, and not a theistic creationist. And creation of the ordered Universe in his cosmology was conceived not as a single event of primordial past, but as eternal dynamic process of periodic 'kindling and going out' of the 'ever-living fire' in an endless series of recurrent cosmic cycles. Therefore, Heraclitus' dynamic "creationism" should be compared not with the Biblical creation story or Pato's Timaeus, but

things through and through", i.e. all things in their totality, an archaic phrase for 'Universe' also attested in Parmenides B 1.32).

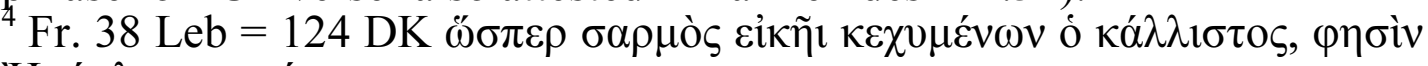

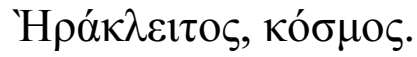


with modern "process theology" (Alfred Whitehead), the ideas of Pierre Theihard de Chardin, Vladimir Vernadsky's concept of noosphere, as well as with certain aspects of the Neoplatonic

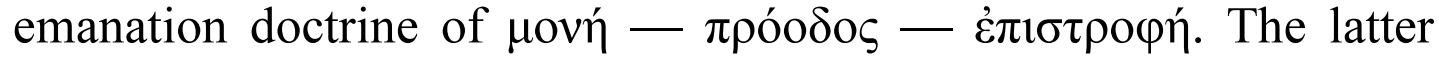
corresponds to Heraclitus' "way up and down", whereas Heraclitus' future predestinated time of 'Abundance' (victory of the wise 'Fire' over the dull corporeal cosmic masses of Earth, Sea and Whirlwind) resembles Theihard de Chardin's Omega point. The closest parallel to Heraclitus' concept of the divine creator of the Universe is found in the Stoic pantheistic notion of 'Nature-Craftsman' ( $\varphi v ́ \sigma ı$ $\tau \varepsilon \chi v i ́ \tau \eta$, natura artifex) which is directly derived from Heraclitus.

Unlike the Milesians, Heraclitus in his philosophy of nature did not deal at all with the etiological explanation of individual natural phenomena which was the core of the standard Ionian treatises Пepì

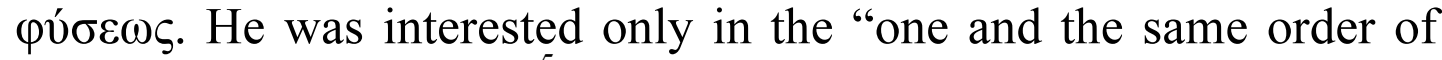
behavior of all beings" 5 , the divine law (theios nomos) of the measure and harmony of opposites, permeating all spheres of cosmic and human life, from the movement of celestial bodies to human 'practices' (technai) in poleis on earth. In the second chapter of the treatise "On Nature", in the 'Logos politikos', which included not only political philosophy and philosophy of law, but also anthropology and ethics, Heraclitus, by dozens of examples or pieces of "confirming evidence" ( $\tau \varepsilon \kappa \mu \eta \dot{p} \rho \alpha)$, strived to demonstrate

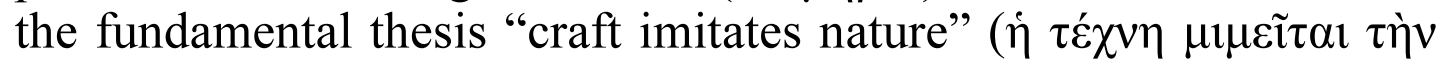

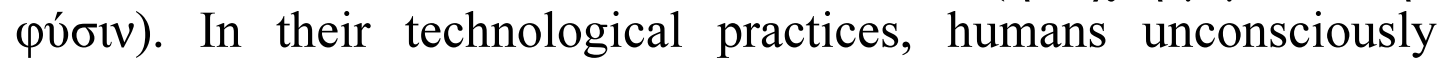
follow the divine law of the harmony and identity of opposites. The thesis "craft imitates nature" is reversible: the "works' (" $p \gamma \alpha$ fr.2 Leb/B1) of nature reveal purposeful operation and intelligent behavior similar to the works of a craftsman. From this it follows that the cosmos is not by origin a random agglomerate of independent parts, but a wisely designed beautiful work of art and at the same time a living organism, as well as a "shared" community of gods and humans, flawlessly ruled by the divine cosmic Mind localized in the Sun, an ideal monarch (identified with Apollo) who strictly adheres to the 'limits' (oũpor) imposed by the "divine law".

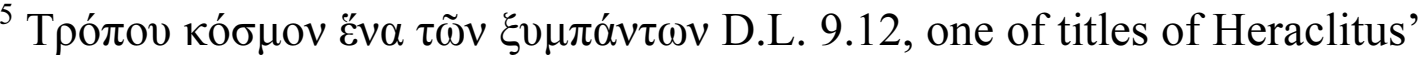
work quoted by Diogenes Laertius. Like $\gamma \nu \omega ́ \mu \eta \dot{\eta} \theta \tilde{\omega} v$, it preserves traces of Ionian dialect and may be based on Heraclitus' text.
} 


\section{The grammatical analogy: the cosmos as a logos (metaphor of liber naturae)}

This section of chapter IV of the Introduction (2014) is now superseded by a substantially expanded version published under the title "The liber naturae metaphor and alphabet analogy in Heraclitus logos-fragments" in: E. Fantino, U. Muss, Ch.Schubert, K. Sier (Hrsg.), "Heraklit im Kontext" (Studia Praesocratica, Vol. 8), Walter de Gruyter: Berlin; New York, 2017. Pp. 231-267.

\section{The mantic metaphoric code: the logos as an oracle}

The mantic or oracular metaphorical code in a certain sense is not metaphorical, since Heraclitus himself believed that he was a prophet of Apollo and that through his mouth speaks the divine wisdom that he "heard" in the divine logos of the Universe just as Pythagoras perceived by his supersensitive ears the cosmic music of the celestial Sirens. Once we admit that "this logos" in the fragments 1Leb/B50 and 2Leb/B1 at the iconic level of meaning is not just a speech or a text, that should be correctly "divided" and "read", but an oracular text, a $\chi \rho \eta \sigma \mu o ́ s$, to be interpreted by a special hermeneutic technique, the grammatical (alphabet) analogy and the mantic (oracular) metaphorical codes merge into a single whole, or rather, the mantic code is superimposed on the grammatical one, since the interpretation of an oracle does not exclude, but requires its preliminary correct "division" (diairesis). In favor of this speaks fr. $27 \mathrm{Leb} / \mathrm{B} 93$ which asserts that the cognition of truth and reality is similar to the interpretation of the oracles of Apollo and his prophetic "signs", as well as fr.160 L/B92 which compares the logos of Heraclitus with the prophetic voice of Sibyl. In Lucian's imitation of Heraclitus' style his speech (that is his "logos") is directly compared with the ambiguous oracles of Apollo Loxias. The oracular text is "obscure" and unclear to the crowd due to its intentional ambiguity: it has a deceptive surface meaning, and a deep, hidden true meaning.

The surface meaning confuses the profane, only a skillful interpreter can get to the true meaning. "The nature of things is hidden" (Fr.25Leb/B8). The parable of the death of Homer and the world riddle (Fr. 20Leb/B21) says that in the cognition of the world men have been "deceived by the appearances" like Homer, who could not solve the riddle of the fishermen. In the passage of Plato's Cratylus about the etymology of the name "Pan", which we regard an unnoticed quotation from Heraclitus (see Fragmenta probabilia 
No.3 with commentary in our edition) Plato says that the LogosUniverse can be true and false. This means that when read incorrectly (as "many") the world-as-text is false, and when read correctly (as "one"), it is true. The true upper (celestial) part of the logos is divine, and the false lower (earthen) part is human; the latter is associated with poetic myths and lies of "tragic" life. Now it becomes clear what was Homer's mistake according to Heraclitus' Fr. 20Leb/B21: Homer confused lice, which are killed when 'grasped' and therefore become less, with fishes which become "more" when caught. He could not understand the logic of the paradox "the more we grasp, the less we have" because he was thinking about fish, not about lice. Homer mistook the letters of the cosmic alphabet (which denote nothing), out of which the LogosUniverse is composed, for real names of some real beings, as a result of which he saw many gods in the phenomenal world of $\tau \grave{\alpha}$ pavepó, although in reality there is only one true god hidden behind the deceptive appearances. The results of our study also explain why quotations from Heraclitus play such important role in the Pythian dialogues of Plutarch and at the same time show that the Stoic theological interpretation of Heraclitus' logos was based on a better understanding of his metaphorical language and on a more adequate understanding of his philosophy in general, than the one that was followed by the adherents of the positivist interpretation, who saw in Heraclitus logos a scientific "formula of things".

Traces of the mantic metaphorical code can be detected in the terminology that Heraclitus employs in connection with the interpretation of "this logos" un fr. 2 Leb/B1 DK: the terms $\varphi \rho \alpha ́ \zeta \omega$ and $\delta$ iaıpé $\omega$ were part of the professional lexicon of the diviners (manteis) $)^{6}$. The verb $\pi \varepsilon i \rho \tilde{\alpha} \sigma \theta \alpha \imath$ ( $\left.\pi \varepsilon \imath \rho \omega ́ \mu \varepsilon v o r\right)$ can mean "to enquire an oracle', literally 'to make trial of' . The mantic code also explains

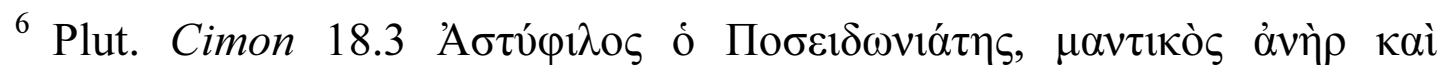

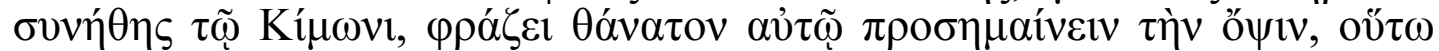

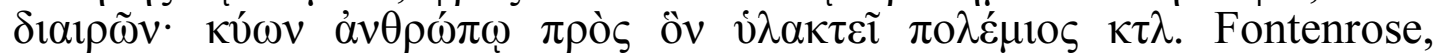
Delphic Oracle, 170: $\varphi$ á $\zeta \varepsilon 0$ is often found in the beginning of oracular response. In Parmenid. B $1.4 \pi 0 \lambda \hat{\varphi} \varphi \rho \alpha \sigma \tau o l ~ i \pi \pi o l$, the wise 'horses' of revelation, carry the Apollonian Kouros to the celestial oracle of Aletheia: on the oracular metaphorical code in Parmenids' proem see Lebedev $2017^{2}$,

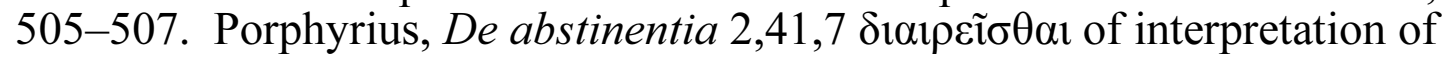

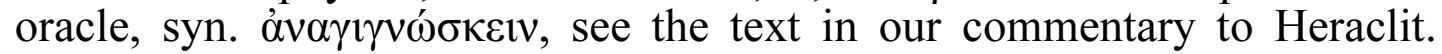
fr. 27 Leb/B93.

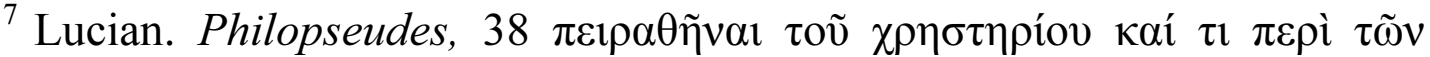

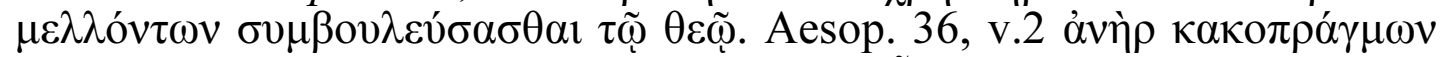

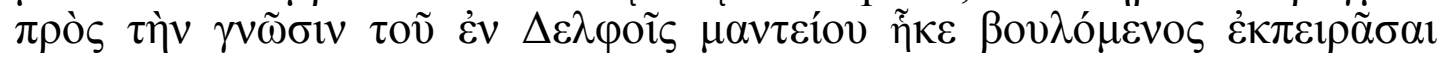


the choice of the word $\varepsilon^{\prime} \pi \eta(\pi \varepsilon 1 \rho \omega ́ \mu \varepsilon v o r ~ \dot{\varepsilon} \pi \varepsilon \dot{\varepsilon} \omega v)$ as a synonym for $\lambda$ ófov $\tau$ óv $\delta \varepsilon$ : on the iconic level an oracle in hexameter verses is meant. On the referential level the cosmos (book of nature) is meant, conceived as a true "epic" and contrasted with the false epic of Homer and the poets. It follows that the theme of "the ancient quarrel" between philosophy and poetry is already present at the very beginning of the book of Heraclitus. Another fragment that may be linked with the motif of the "wisdom of Apollo" and that employs mantic metaphorical code is fr. $97 \mathrm{Leb} / \mathrm{B} 101 \dot{\varepsilon} \delta 1 \zeta \eta \sigma \alpha ́ \mu \eta \nu$

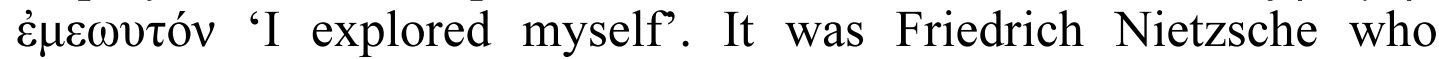
pointed out that $\dot{\varepsilon} \delta i \zeta \eta \sigma \alpha ́ \mu \eta \nu$ alludes to the interpretation of an oracle, which is confirmed by one passage in Herodotus ${ }^{8}$. Plutarch quotes this saying as a response of Heraclitus to the imperative of

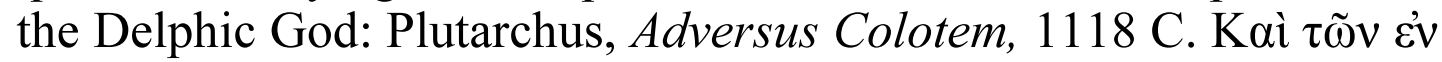

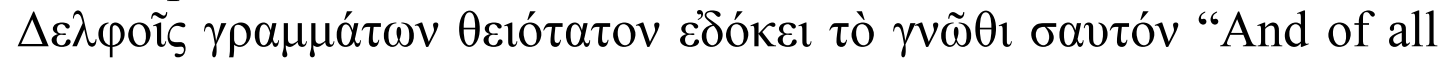
Delphic inscriptions he regarded as the most divine the saying "know thyself". This unique evidence of Plutarch should be treated not as Plutarch's own interpretation, but as a paraphrase or a summary of Heraclitus' context, i.e. as a separate fragment of Heraclitus with one word, $\theta \varepsilon$ có $\alpha \alpha \tau o v$, as a possible verbatim quotation from Heraclitus' book (Heraclitus, fragment 98 in our collection). Heraclitus quotes an apophthegm of one of the Seven

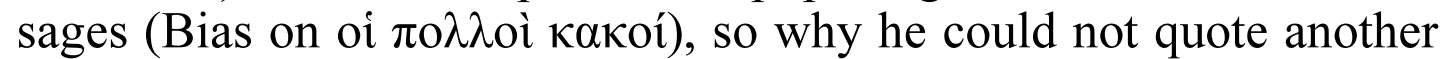
one ( $\gamma v \tilde{\omega} \theta \imath$ $\sigma \varepsilon \alpha v \tau o ́ v)$ when Plutarch assuredly states that he did?

\section{Agonistic model: the cosmos as a stadium}

The agonistic model of the cosmos is reliably attested both in the authentic fragments and in the secondary sources 9 . It is closely tied by the relationship of metaphorical synonymity with the military and economic (lend-and-borrow) codes, as well as with the game (lusoria tabula) metaphorical code. In the sources these codes are sometimes intertwined. It is these codes that are most appropriate

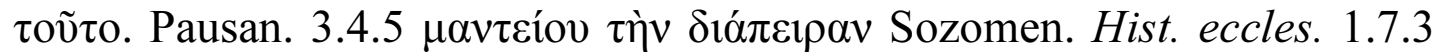

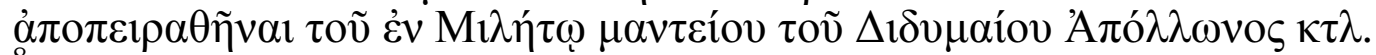

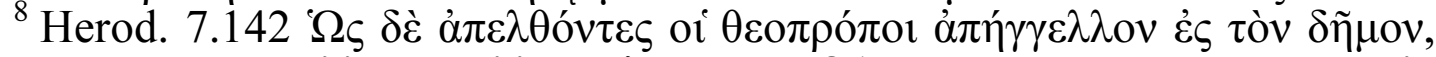

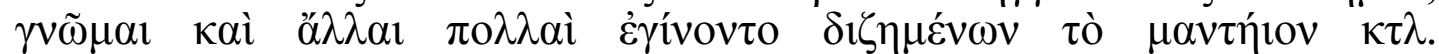
Fr.Nietzsche, Preplatonic philosophers, Urbana \& Chicago, 2001, p. 56.

9 "The cosmos as a stadium..." (1985) and "The imagery of lampadedromia..." (1988). The relevant fragments are 50-51A = B60, A8 DK; Leb, 55-57 Leb = B 120, B 100 and Derveni papyrus col.IV; lampadedromia fr.78-80 Leb. $=$ B 20, 84a-b DK. with comm. On the agonistic aspects of Greek culture in general see Zaicev (2002). 
and adequate for iconic representation of the relationship between conflicting or competing cosmic forces as well as of the reciprocity and mutual interdependence of two members of a single pair. The agonistic competition of athletes in the stadium is analogous to the war of opponents on the battlefield, to the winning and losing of players in pesseia, as well as to participants in binary transactions debtors and creditors, sellers and buyers. The agonistic code differs from other members of this group in that it is simultaneously parallel to the "river code" comprising metaphors for the universal flux and change of all things.

The metaphors of "running, race" and "flowing", distinct on the iconic level (stadium or road, one the one hand, and river on the other), convey the same referential concept of rapid movement and change. In English we speak about "running water", the verb meчb ('to flow' in Modern Russian), was regularly used in the Old Slavonic and Old Russian in the sense 'to run' and was used as translation of Greek $\tau \rho \varepsilon \dot{\chi} \omega$. The third metaphorical synonym of "river" and "stadium" in Heraclitus is the kykeon, a symbol of the ongoing movement that ensures stability and homeostasis of the body and the cosmos. In order to differentiate agonistic and "river" metaphor in secondary sources (paraphrases, reminiscences etc. in the Heraclitean tradition) it is necessary to keep in mind that only the words $\rho \dot{\varepsilon} \omega$, $\rho$ on 'flow, flux' are connected with the river symbol, while the verbs 'go, pass, run, change place, turn around, run over a

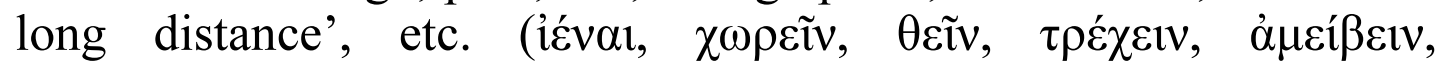
$\dot{\alpha} v \alpha \kappa \alpha \dot{\mu} \mu \pi \tau \varepsilon ı v, \delta o \lambda \imath \chi \varepsilon v \varepsilon \varepsilon v v)$ are associated with the image of the stadium (or sometimes the hippodrome) or of a road, and not with the river image; the flux metaphors do not pertain to the agonistic (athletic) metaphorical code. In Heraclitus' original text the image of river was applied not to the macro-, but to the microcosm, i. e. to man, and it primarily illustrated the process of "exhalation" of souls from blood, assimilating human souls to "rivers". (We do not exclude that in some contexts, speaking about the parallelism between the macrocosmic and microcosmic psyche-anathymiasis, Heraclitus could apply the image of river and flux to both). Only in Plato's free paraphrase the "Heraclitean river" became a symbol of the universal change of all things. Note that Heraclitus could not even speak of $\tau \grave{\alpha}$ őv $\tau \alpha$ in plurals since he recognized only one őv. His authentic term for (deceptive) plurality of things is $\pi \alpha ́ v \tau \alpha$

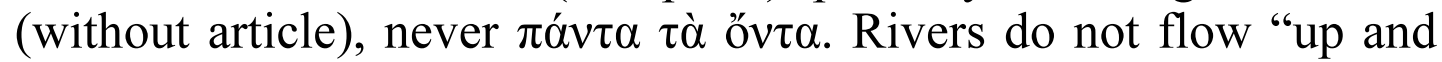

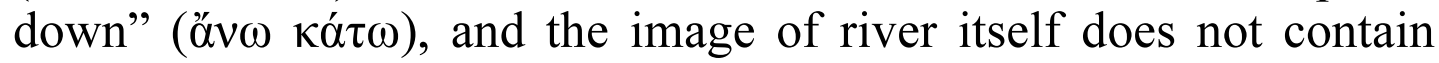
iconic equivalents of the opposing forces, which play so important 
part in Heraclitus' philosophy of nature, it contains only the

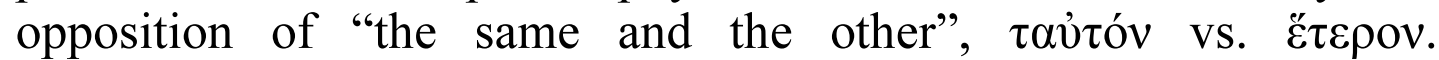
Therefore, it was the agonistic model that was predominantly Heraclitus' own model of universal movement and cosmic change. Unlike the image of the river, it not only contains opposing iconic equivalents of opposite powers (competing athletes), but also clearly expresses the idea of a programmed regularity of change. Unlike modern stadiums, in Greek stadiums they ran not in a circle, but in a straight line, turning 180 degrees at the finish line (if it was not a simple "stadion race", but a double-diaulos or long-dolichos) and returned back to the start. In athletic language, the runner's course from start to finish was called ódòs ôv $\omega$ 'road up', and the return

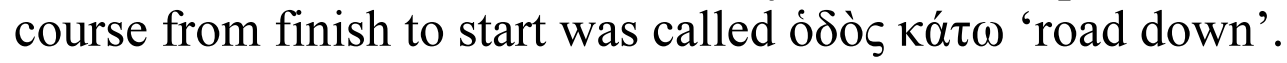

It was the stadium race track, in Heraclitus' poetic "cosmology", and not just a road (like the one from Athens to Thebes) that was a

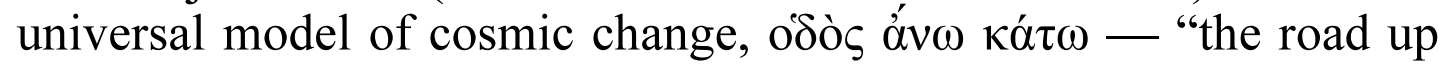
and down"), conceived as a cyclic (pendulum-like) and predetermined process of interchange of opposites which constantly "run" from minimum-point to maximum-point and backwards. Turning points in stadiums were marked with "turning posts" ( $\tau \dot{\varepsilon} \rho \mu \alpha \tau \alpha)$. In Fr. 55 Leb/B120 DK Heraclitus metaphorically calls by this name the turning points of the year ( $\tau \rho \circ \pi \alpha i)$, the spring and autumn equinox, when Day and Night (Sunrise and Sunset) begin to get "bigger and smaller" than adversary until the next "reversals". At the point of the summer solstice ( $\tau \rho \circ \pi \alpha i)$, they will stop, and "will change their paths": Day from the "road up" (increase) to the "road down" (decrease), and Night from the "road down" to the "road up". The mathematically calculated accuracy and "justice" of these changes, according to Heraclitus, could not be accidental: it pointed to an invisible regulator or moderator, the divine cosmic mind ( $\nu \omega \omega \mu \eta)$. In the agonistic model, the moderator becomes the Umpire

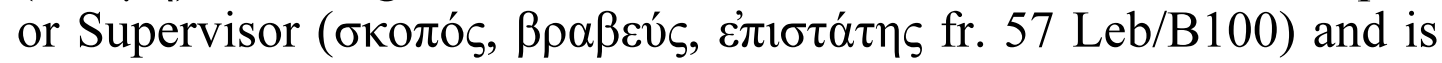
identified with the Sun, which regulates the cycles of day and night, as well as of the seasons (Horai). Greek athletes before the start of the competition took an oath not to violate the rules. Oath breakers according to popular belief were punished by Erinyes, the goddesses of revenge. It can be assumed that in some oaths the one who gave it, finished his swearing with the words "and if I break this oath, let me be punished by Erinyes, the ministers of Justice!" In this case, the use of this formula of conditional self-curse in Fr. 56 Leb (= B94 + Derveni pap., col. IV,9) is simply a rhetorical circumlocution (imitating Apollo Loxias' language) meaning that the Sun itself is 
bound by a great oath (the divine law of fr. $131 \mathrm{Leb} / \mathrm{B} 114$ ), which it can never break. The oath is an archaic form of a contract, and the contract in Greek, in particular, could be called logos (LSJ, s.v. $\lambda$ ó ${ }^{\circ} \varsigma$, VII 4). A close parallel to such metonymical use of "oath" (horkos) in the sense of "law" is provided by Empedocles who speaks of "ancient decree of the gods," that is, the divine law prohibiting bloodshed, which is "sealed with broad oaths" $31 \mathrm{~B} 115$, i. e. spread over wide space and unbreakable. The reconstruction of the stadium model helps to resolve the debate of commentators that has never stopped since the 19th century, whether Heraclitus held himself a theory of the Universal Flux or it is a later doxographical aberration that goes back to some passages in Plato. Eduard Zeller firmly adhered to the traditional interpretation, going back to Plato, Aristotle and doxography. In the 20th century, a skeptical school of thought (Burnet, Reinhardt, Vlastos, Kirk, Marcovich and many others) became prevalent among students of Heraclitus. Those who denied the authenticity of the theory of universal flux, as a rule denied also the authenticity of the periodical cosmic conflagration (ecpyrosis), and emphasized the "quantitative" rather that temporal meaning of the so called "cosmic measures" in Heraclitus' cosmology. Some serious voices of dissent have sounded in recent decades. Jonathan Barnes advocated trust in Plato and Aristotle (Barnes 1979: I: 65 "Flux is Heraclitean"), Charles Kahn recognized ecpyrosis, criticized the quantitative and static interpretation of Heraclitus' cosmology, and rightly pointed out the temporal nature of "measures" (metra) and its inextricable connection with the periodic cosmic cycle (Kahn HCF: 147-153). Marcel Conche defiantly included the famous dictum "everything flows" ( $\pi \alpha ́ v \tau \alpha$ $\dot{\rho} \varepsilon \tilde{\imath})$ in his edition of Heraclitus' fragments (Conche HF, fr.136, p. 466). But the positivist interpretation of Heraclitus advanced by Burnet is not going to give up positions: Graham (FEGP I 135, 139) still denies the "strong" interpretation of the identity of opposites and the authenticity of ecpyrosis.

The agonistic model of the cosmos, that we extracted in 1985 from the darkness of oblivion, changes the picture and, with some reservations, provides a new substantial support to the traditional view. Even if Heraclitus didn't say literally that everything is flowing, he clearly says in genuine fragments that everything is running, and running incessantly and at a high speed of a stadium race. The race of cosmic opposites only slows down for a moment at the point of "reversals", when they change their course for the opposite direction and shift from "the way up" to "the way down" 
( $\mu \varepsilon \tau \alpha \beta \alpha \dot{\alpha} \lambda \lambda$ ov $\dot{\alpha} v \alpha \pi \alpha v ́ \varepsilon \tau \alpha l$ ). The cosmos operates like a pendulum, it literally goes back and forth in perpetual cycling according to

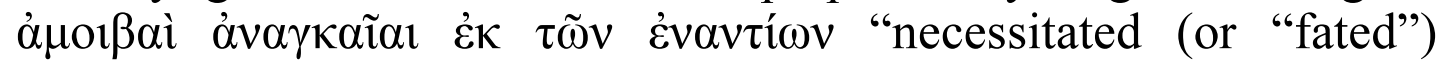
changes from the contraries" (neglected verbatim Heraclitus quotation in Plotinus, fr.52 Leb in our edition). This model contrary to Burnet and his followers - confirms the temporal, cyclical nature of the so called cosmic "measures". All ancient readers of Heraclitus unanimously understood the word $\mu \varepsilon \dot{\tau} \rho \alpha$ in fr.37 Leb/B30 DK adverbially with a reference to "measured periods of time", and not to some measured volumes of matter, as Burnet's far-fetched interpretation would like us to believe ${ }^{10}$. These measured periods of time or cosmic cycles, hierarchically arranged from shortest to longest, were enumerated by Heraclitus in the following context, i.e. in fr. 43 Leb/B67 DK: diurnal ("day and night"), annual ("winter and summer") and periods of the Great Year "Excess and Need" or "Wealth and Poverty" of fire ". Burnet and his followers tried to support their materialist interpretation of cosmic "measures" in Heraclitus by citing another supposed instance of $\mu \varepsilon ́ \tau \rho \alpha$ in Heraclitus, the fragment on the Sun and Erinyes fr.56Leb/B94 in which $\mu \varepsilon \tau^{\prime} \rho \alpha$ allegedly refers the size of the sun. Plutarch quotes this fragment twice from memory with divergent readings $\mu \varepsilon ́ \tau \rho \alpha$ in $D e$ exilio 604A and oopovs in De Iside 370D. The verbatim quotation in Derveni papyrus col. IV,8 (apparently from a written source because of its extension and pure Ionian dialect) proves that the authentic

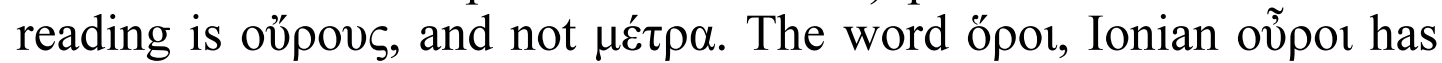
nothing to do with "measured volumes of matter"; it is even more often that $\mu \varepsilon \dot{\tau} \tau \alpha$ associated with temporal "limits" and fixed "terms" or terminal points of time. In Heraclitus fr.55 Leb/B120 the phrase

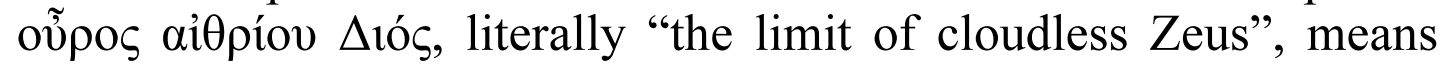

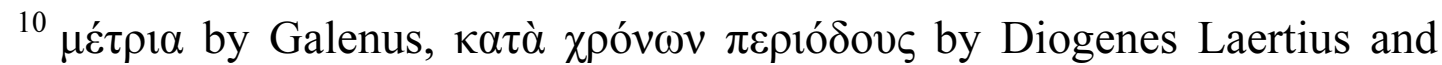

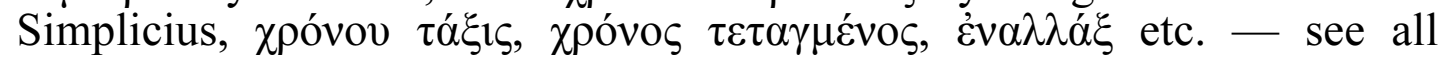
testimonia to fr. 51 in Marcovich's edition. The author of De mundo

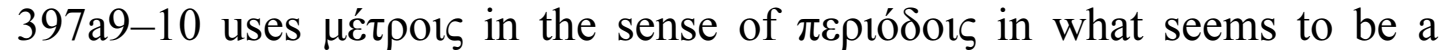
neglected paraphrase of Heraclitus fr.37Leb/B3O in his elaboration on

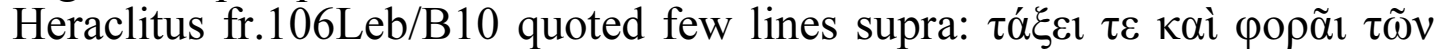

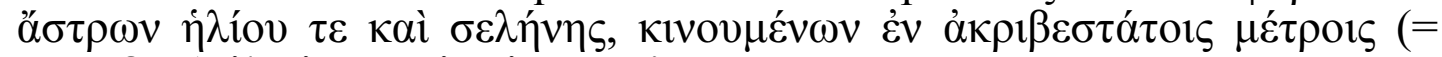

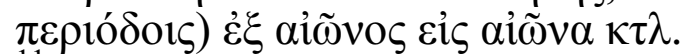

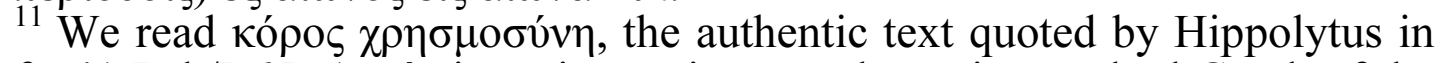

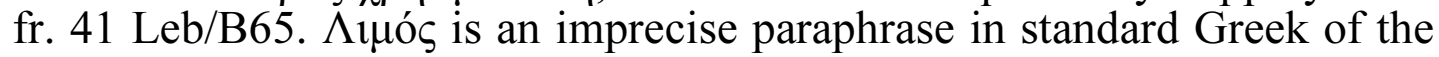
archaic Ionian word $\chi \rho \eta \sigma \mu о \sigma u ́ v \eta$. In later Greek and in patristic authors кópos has predominantly a narrow sense of 'satiety' opposed to 'hunger'. In Heraclitus, as in archaic poetry (Theognis, Solon), אópos 'abundance' is associated with 'wealth' (ő $\left.\lambda \beta \beta_{\varsigma}\right)$ opposed to 'need' or 'poverty'. 
"the limit of the (period) of clear sky", i. e. the end of good weather, and refers to the autumnal equinox which is "opposite to Arktos", $i$. e. to the time of upper culmination of the constellation of Great Bear which in northern hemisphere falls on the end of March, i. e. coincides with the vernal equinox ${ }^{12}$. Our reconstruction of the economic (lend-and-borrow) metaphorical code also confirms the temporal nature of the cosmic metra, since the repayment of debt

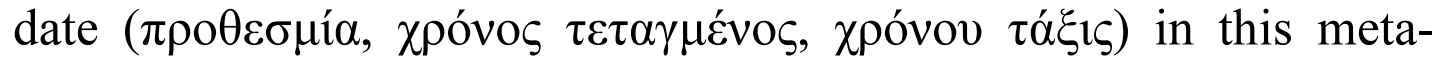
phorical analogy refers to a predefined moment of time in the cosmic cycle. The comparison of the exchange of "all things" for fire with a mortgage (i $\pi \alpha \lambda \lambda \alpha \gamma \eta$ ) loan in fr. 42 Leb/B90 DK unequivocally proves the authenticity of the world conflagration (ecpyrosis) and its connection with the idea of fate $(\dot{\alpha} \mu \circ \beta \alpha i$

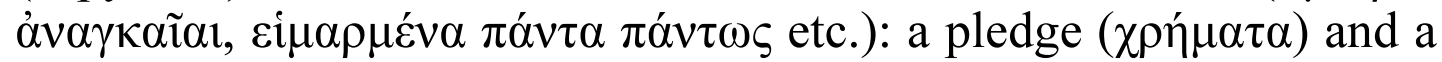
loan $(\chi \rho v \sigma o ́ \varsigma)$ cannot be in the same hands at the same time, and a repayment period of "abundance" (domination) of fire is inevitable.

The agonistic model is important not only for the debate on the universal flux in Heraclitus, but also for understanding the fundamental doctrine of unity and harmony of opposites in Heraclitus' philosophy. It is in the agonistic model that the Umpire or Moderator stands above the opposing forces. This radically changes the meaning of the doctrine of opposites and transforms it from an abstract metaphysical scheme into a practical political theory: in more detail we discuss the "triadic structure" $(2+1$ formula) in Heraclitus' metaphysics in the chapter "An outline of the philosophy of Heraclitus" (Lebedev 2014). See also our commentary on fragments either containing agonistic metaphors or describing real agonistic practices that are listed in fr.122Leb.

\section{Military model: the cosmos as a battlefield}

The key terms of this metaphorical code are "war" ( $\pi$ ó $\lambda \varepsilon \mu \rho \varsigma)$

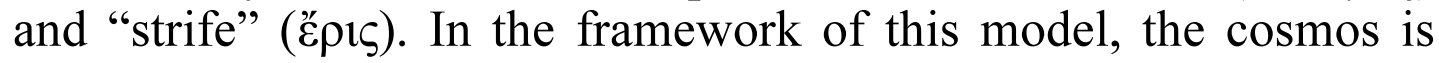
conceived as a battlefield, the opposites (which means "all things",

12 I am grateful to late distinguished astronomers Lidiia Nikolaevna Radlova (1913-1999) and Boris Iul'evich Levin (1912-1989), a renowned cosmogonist, for the astronomical consultation in 1985 which confirmed my guess on the possible connection of B120 DK with equinoxes. I was certain that "the limit of clear sky (Zeus)" refers to autumnal equinox, but was puzzled by the connection of Arktos with spring equinox. This explanation was proposed in my 1985 article "The cosmos as a stadium" published the same year in Phronesis; as it seems, it has remained unnoticed for the last 35 years. 
$\pi \alpha ́ v \tau \alpha$, since no cosmic phenomenon or power exists by itself without pair) as opponents and enemies, the cosmic processes are described as alternating "attack" and "retreat" corresponding to "increase and decrease", "scatter and replenish", "borrow and repay" in the economic code. The word $\chi \omega \rho \varepsilon \tilde{\imath}$ ( $\pi \dot{v} v \tau \alpha \chi \omega \rho \varepsilon \tilde{\imath}$ is a verbatim quotation fr.48 Leb) in Homer is used in military contexts for "for giving way" to advancing enemy. So, all things not just "pass", but retreat giving way to advancing adversaries. The last judgement at the end of the Megas Eniautos is conceived as an "attack of Fire" ( $\pi \tilde{v} \rho \dot{\varepsilon} \pi \varepsilon \lambda \theta o ́ v):$ on $\dot{\varepsilon} \pi \dot{\varepsilon} \rho \chi 0 \mu \alpha$ in military contexts

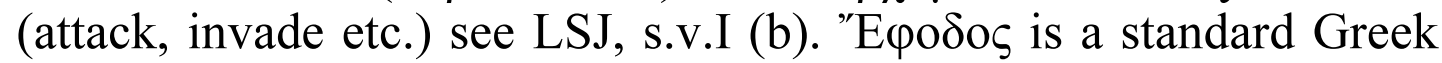
military term for "attack" (LSJ, s.v. II). The Hippocratic author of De diaeta perfectly understood this metaphorical language of Heraclitus and imitated it: he explains the solar and lunar cycles as

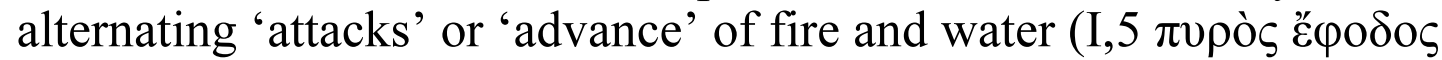
$\kappa \alpha \tilde{i}$ vँ $\delta \alpha \tau o \varsigma)$. Due to the paradoxical identification of war and harmony, Polemos becomes in Heraclitus the main cosmic and "divine" law to which absolutely all beings are subordinate: cosmic elements, luminaries, gods and humans, animals etc. In the fr. 32 Leb/B53 the personification of war - Polemos - replaces the name of Zeus in the epic formula of the supreme god "the father and king of men and gods." "Victory" in the military metaphorical code corresponds to "wealth, abundance" (кópo $\varsigma$ ) in the economic code, and "defeat" - to "poverty" or "need" ( $\chi \rho \eta \sigma \mu о \sigma v ́ v \eta)$. The "attack" of Fire at the time of ecpyrosis is also his "victory" over all other cosmic masses (Earth, Sea and Prester-Air) in the great cosmic battle of elements described in fr. 44-45 Leb/ B31 DK. The cosmic war proceeds according to strict rules and with cyclical regularity: the adversaries take turns traversing "the road up and down" from

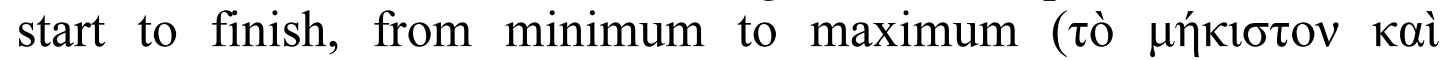
$\dot{\varepsilon} \lambda \alpha \alpha \chi 1 \sigma \tau o v$ in De diaeta I,5), advancing and retreating, "turning around" from increase to decrease et vice versa at the predefined

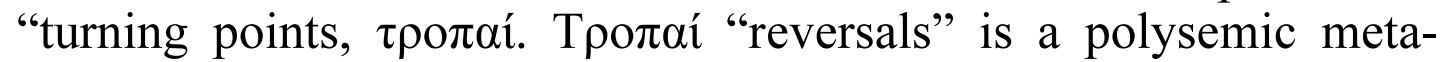
phor: in military language, $\tau \rho о \pi \eta ́$ was a decisive moment when one of the parties, unable to withstand the enemy's attack, "turned around" and fled; at this spot the winners used to put a "turning

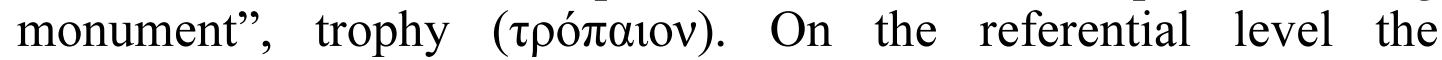
"reversals" (tropai) in Heraclitus refer to astronomical "turning points" in the structure of a calendar year (as well as of Great Year), i. e. to solstices and equinoxes ${ }^{13}$.

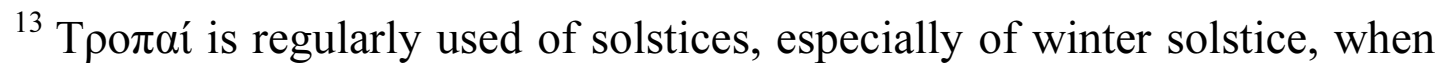


Fragments 44-45Leb (B31 DK) were misinterpreted already by the Stoic source of Clement as a cosmogony describing material transformations of the simple first element (fire) into a diverse cosmos. This error is due to the incorrect interpretation of the word $\tau \rho о \pi \eta$ as 'transformation'. It can sometimes mean "change" like a change of weather, but it never denotes a material transformation of something, a transformed object. Bruno Snell in his 1926 article on Heraclitus' language rightly pointed out that in archaic Ionian prose such meaning should be ruled out ${ }^{14}$. Fragments $44-45$ Leb on the iconic level describe a grandiose cosmic battle of the four world masses (Fire, Wind-Prester, Sea and Earth), cold Prester fights with hot Fire, wet Sea with dry Earth. At the referential level this battle encodes a calendar of the Great Year, in which the change of "seasons" corresponds to the successive domination of each of the four elements (the cosmic cycle of Empedocles provides a striking parallel) ${ }^{15}$. This interpretation is additionally confirmed by the evidence of the scholia to Nicander (fr. 45B Leb/A 14a DK), a neglected paraphrase of fr. 44-45 Leb/B 31 (and may be of the part if its wider context that is not preserved elsewhere) which provides a connecting link between the fragment about Polemos and the "cosmogony" of fr. 44-45: the Sea and Fire are attacked in the cosmic battle of elements, subjugated and "enslaved" by the enemy "storm-winds", i. e. by Prester of Heraclitus' original text. The doxography speaks of abstract "opposites" ( $\tau \grave{\alpha}$ Évavtía) in Heraclitus, but in the authentic fragments this term of the 4th century (and later) does not occur ${ }^{16}$. The closest authentic analogue is the term "the hostile" ( $\tau$ ò $\dot{\alpha} v \tau i \xi$ ovv) 34Leb/B8 taken from the military language ${ }^{17}$.

used alone. But it was also occasionally used of the moon and other luminaries, and also applied to solstices and equinoxes together, as in Sext.Emp. 5.11 (LSJ, s.v.I b).

${ }^{14}$ Bruno Snell, Die Sprache Heraklits (1926) 359-360 and note (1). Snell correctly criticizes Diels's 'Wandlungen' and connects $\tau$ po $\pi \alpha i$ with 'Sonnenwende', but his impressionist ('Erlebnis') reading of the fragment is mistaken and does not support Reinhardt's denial of ecpyrosis.

${ }^{15}$ We do not ascribe to Heraclitus Empedocles' "chemical" concept of elements, by four elements we mean "maxima membra mundi" which, unlike the Empedoclean elements, are constantly transformed into each other. ${ }^{16}$ One cannot exclude the authenticity of the phrase $\dot{\varepsilon} \kappa \tau \tilde{\omega} v \dot{\varepsilon} v \alpha v \tau i$ í $\omega v$ in Plotinus' quotation (Heraclit. fr.52 Leb), but in such case this is a gen. plur.

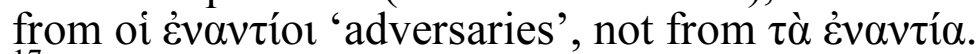

${ }^{17} 6$ out of 9 instances of $\dot{\alpha} v \tau\{\dot{\xi}$ oo $\zeta$ in Herodotus (Powell, Lex. Her. s.v. and TLG) come from military contexts, in two cases it is applied to army: 6.7 
One should note the special proximity (metaphorical synonymity) of military and economic (lend-and-borrow) metaphorical codes in Heraclitus: in Fr. 31 Leb/B80 they are intertwined, "borrowing" $(\chi \rho \varepsilon \omega ́ \mu \varepsilon v \alpha)$, "or living at the expense of other's death" is understood as a war and strife, debtors and creditors are compared with military adversaries. For the ancient reader, such associations did not seem strange: both those who did not repay a debt and those who lost a battle became slaves. We can say that the idea of class struggle as the law of history was invented by Heraclitus, and not by Karl Marx. However, Heraclitus would not approve of the idea of the proletarian revolution and the destruction of one class by another: in his opinion, this would lead to the collapse of the whole system and to the extinction of the human race. Both the military and the lend-and-borrow metaphorical code, in turn, are "parallel" to the agonistic, political and gaming codes. In all cases, it is a matter of competition between two parties, and in all cases, winning of the one side means losing of the other. It can be assumed that "strife" or "rivalry" (Épls) is Heraclitus' general term for all specific types of competitive relations on which human society is based just as the 'Republic of Zeus' (cosmos) is based on the competitive interaction of cosmic powers supervised by the impartial Moderator who transforms their conflict (agon) into palintropos harmonia, literally 'turning back' or 'reversive' harmony.

Together, these codes belong to the sociomorphic type, which differs from the biomorphic and technomorphic in that it is better suited to describe not cosmogony in the proper sense, not the origin (birth or creation) of the world, but the organization, functioning and "management" of the world system. Since the book of Heraclitus, according to Diodotus, was "On the form of government" (Пєрi $\left.\pi \mathrm{o} \lambda \imath \tau \varepsilon i \alpha_{\varsigma}\right)$, and not "On Nature" (in the Milesian sense of the term), we can now understand why the sociomorphic code (including all its variations) is prevailing in metaphorical language of Heraclitus. The political ideal of Heraclitus was an enlightened monarchy (عi $s$

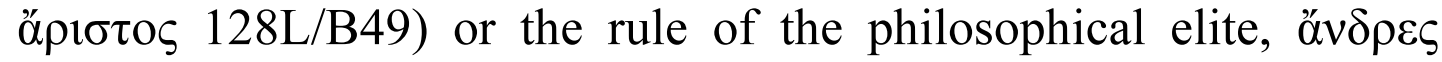

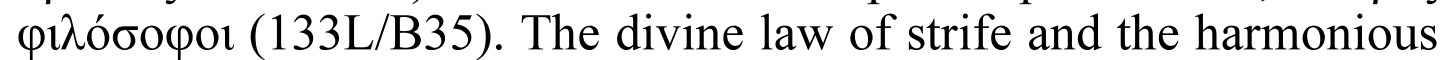
unity of opposites in Fr. 32 Leb (B 53) is explicitly called the "king" ( $\left.\beta \alpha \sigma i \lambda \varepsilon \varepsilon^{\prime}\right)$. In the agonistic code, this wise ruler, standing above the competing parties and saving them from mutual destruction by strict moderation of the eternal conflict (imposing the "limits" of the

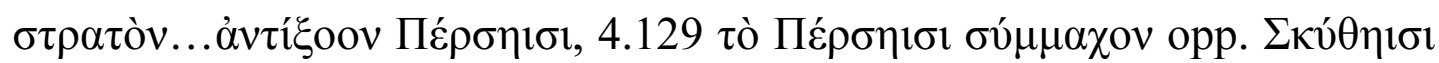

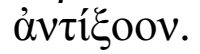


maximum and minimum), transforms into a Judge or an Arbiter (B $\left.\alpha \beta \varepsilon \varepsilon v_{s}\right)$ of the competition, in the economic lend-and-borrow code this is supposedly a loan agreement or contract ( $\lambda$ ó $\left.{ }^{\circ} \varsigma\right)$, "the same" for mortals and immortals according to surprisingly neglected

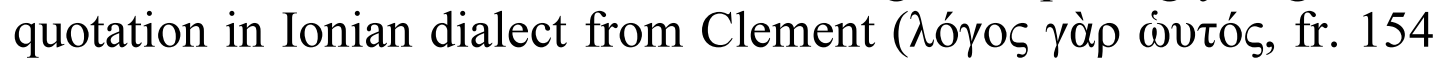
Leb). In the game (pesseia) model it is Time (Aion), moving the game-pieces of gods and humans on a gameboard of life (aióv) according to strict rules and making them to exchange their roles of mortals and immortals, free and slaves, as they win or lose the game (fr. $33 \mathrm{Leb} / \mathrm{B}$ 52). In mythological language, this supreme principle corresponds to Zeus and Apollo who are 'consubstantial' as 'Father and Son': Apollo the Sun is a 'portion' of the purest 'Keraunian' fire, the skillful craftsman-creator and the 'intelligent' ( $\varphi \rho \operatorname{cov}_{\mu} \mu \mathrm{v}$ fr.39 Leb, cf.B64) Pilot of the Universe: $\tau \alpha \dot{\delta} \varepsilon \varepsilon \pi \dot{v} v \tau \alpha$ oi $\alpha \kappa i \zeta \varepsilon 1$ Kepavvós "This Universe is governed by Thunderbolt" (fr.40 Leb/B64). Heraclitus also refers to this supreme principle in nonanthropomorphic, more abstract terms, such as Logos, Harmony and Techne. We call this figure, referred to by many metaphorical names, but essentially the same, the Moderator. In metaphysics, theology and philosophy of nature of Heraclitus (which serve as a "paradigm" for his political philosophy and a foundation of his ethical philosophy), the formula "Two plus One", comprising two opposites and one Moderator, is what we call the triadic structure. In Greek political philosophy and practice, the idea of the beneficial "Third party", of an impartial Mediator or $\Delta 1 \alpha \imath \tau \eta \tau$ 's, standing outside and above the conflicting parties and saving them from mutual destruction, was not new, it goes back to Solon, the father of Greek political "centrism". But Heraclitus, unlike Solon, grounded it in a metaphysical and theological foundation, creating the first consistent theory of natural law and expressing it in the language of metaphorical parables, to which he owed the later nickname "Obscure". The dominant position of the theme of "strife" and "war" in the texts of Heraclitus is explained, apart from philosophical tasks, also by urgent practical needs at the time during the Ionian revolt or after its bloody suppression by the Persians in 494 B.C.

The study of Heraclitus'biography has led us to conclusion that he sided with the party of war in Ephesus that faced opposition from the persophile party of reconciliation. The "pacifist" supporters of the latter party probably cited Homer's condemnation of strife in the famous verse of "Iliad" turning it into the current slogan of peace. This explains why Heraclitus attacks Homer (and another "pacifist" 
Archilochus who boasted that he threw his shield) with such passion, disproves the verse of the Iliad 18.107 and justifies the "naturalness" of the war and strife. He also appeals to the ancient aristocratic ideal of self-sacrifice and heroic death in battle awarded

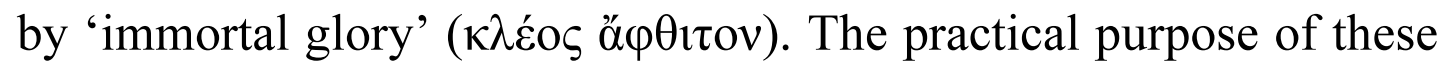
patriotic exhortations was the unification of all Ionian poleis into a single federal state with a common cult of Apollo the Sun, common government and common command, that would defeat the Achaemenid empire and will save the Greeks from slavery (a project ascribed by Herodotus I.170 to Thales).

The main texts on war and strife, military metaphors. Пó $\lambda \varepsilon \mu o s:$

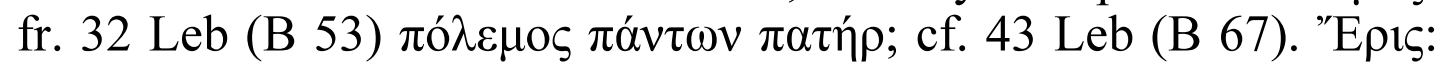

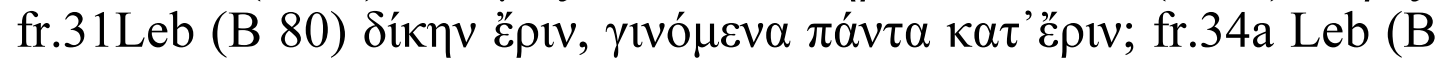

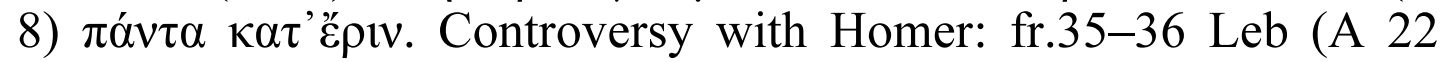
DK). The cosmic cycle of Great Year as a war of four world masses:

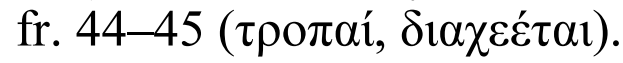

\section{The economic metaphorical code: the cosmos as a household}

The lend-and-borrow economic metaphorical code was invented by Anaximander, who used it in Fr. B1 DK in the first formulation of the law of conservation of matter: "From which /elements/ all things originate, into the same they perish according to a fatal

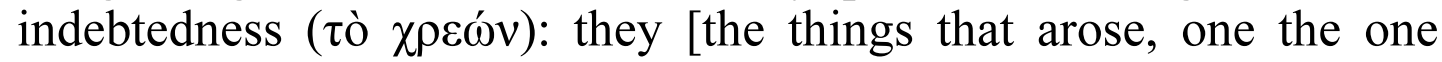
hand, and the original elements, on the other] pay a just recompence among themselves at the appointed time". This is a universal law that applies to all things (animals, men, worlds, etc.), and not to "opposites" in spite of the widespread erroneous interpretation that goes back to Burnet. There is no mention of any "opposites" in Anaximander's own words. Anaximander is not talking about any "reciprocity" or cyclical change. The word $\dot{\alpha} \lambda \lambda \dot{\eta} \lambda$ or $\varsigma$ does not imply any reciprocity, it means nothing and may have been added by Simplicius to clarify that compensation is paid between two groups of eternal elements on the one hand, and generated things, on the other, and not between generated things themselves. The Greek word for cannibalism, $\dot{\alpha} \lambda \lambda \eta \lambda o \varphi \alpha \gamma i$, does not imply that a man A eats a man $B$ and is in his turn eaten by $B$, it just refers to the fact that one member of a group eats another member of the same group, not that they eat each other in turn. Things derive from elements and depend on elements, but elements do not derive from generated things and do not depend on things. These two groups are unequal. Things correspond to "debtors", the elements to "creditors", the 
generation of things out of elements is compared with a loan (borrowing of stuff) secured by one's own body. The lifespan of any being is determined by the "set" debt repayment term ( $\chi$ póvov $\tau \alpha \dot{\alpha} \xi 1 \varsigma$

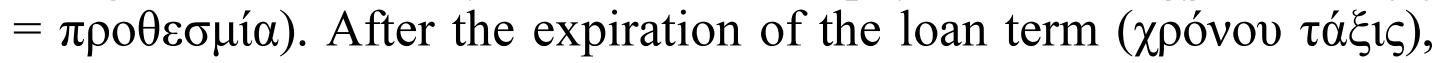

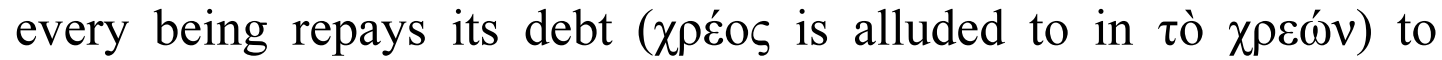

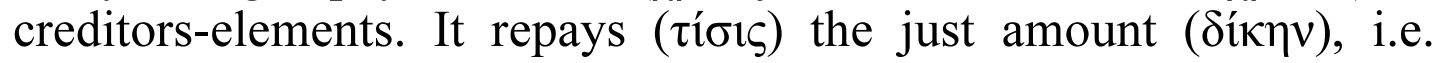
equal to inflicted damage ( $\dot{\alpha} \delta$ ikí is a legal term for damage with no moral or religious connotations). The innumerable worlds after expiration of loan term are dissolved in the "boundless nature" ( Theophrastus and Aristotle is a mixture of different "seeds" like that of Anaxagoras (hence the plural $\dot{\varepsilon} \xi \tilde{\omega} v)^{18}$. Not a single gram of matter is lost in these transactions of nature. In the cosmic household, all expenses are covered by equal recompenses, not a bit of "eternal nature" disappears, only individual beings are born and die due to mechanical reshuffle of particles of matter. Anaximander was a physicist, and he formulated the law of nature, which later became

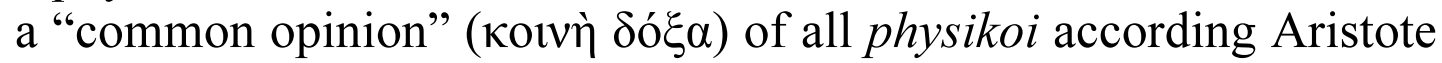
(Phys. 187a27, right after quoting Anaximander in a21), the law ex

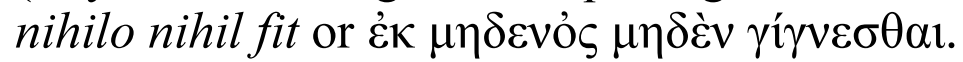

Heraclitus was a moral and political thinker, so he was not so much interested in the laws of nature that have no direct relationship to ethics and politics, but in the idea of cosmic justice, which could become the basis of the theory of natural law and applied to practical legislation. Therefore, he borrowed from Anaximander only a formal scheme, but with two serious modifications. Firstly, it was Heraclitus who first applied the lend-and-borrow analogy to the description of cyclic transmutation of opposites inherent in the same

${ }^{18}$ Tò ö́reipov is not an authentic term of Anaximander, it is Aristotle' own term which he does not even ascribe specifically to Anaximander in Phys.

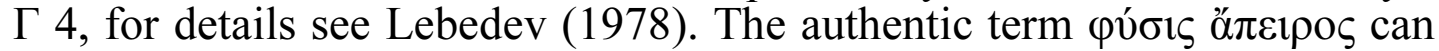
be reconstructed on the basis of Hippolytus' doxography which quotes the

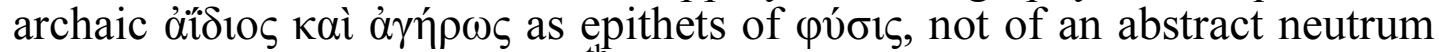

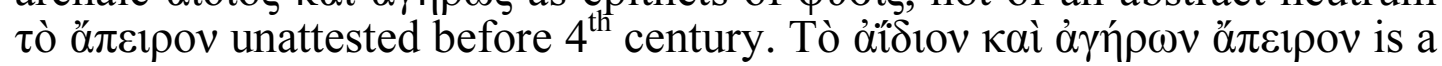

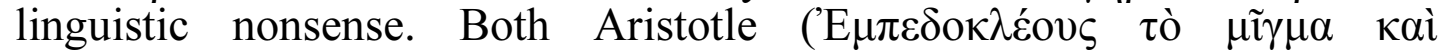

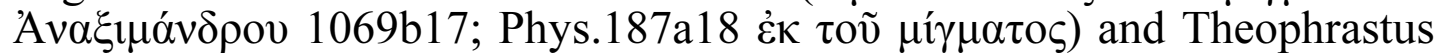

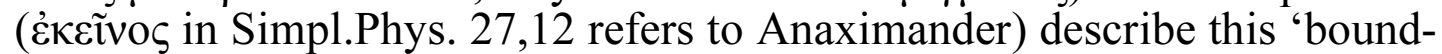
less nature' of Anaximander as a 'mixture' similar to the panspermia of Anaxagoras. I cannot see how one can neglect this precise evidence and consensus of the earliest sources, of two independent readers of Anaximander's book, and rely on second hand imperial doxography. For a defense of the panspermia interpretation of Anaximander's 'boundless nature' see Lebedev (1988). 
single substrate. This is impossible in the mechanistic physics of Anaximander, since all the processes of change are understood in it as recombination of corpuscles: separation from a mixture, combination, dissolution, but not alterations of a substrate. Secondly, the materialist law of nature, the principle of ex nihilo nihil, in the context of the teleological holism of Heraclitus has been

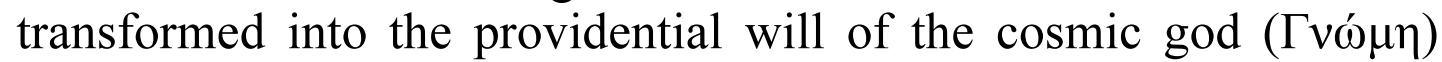
and the inevitability of Destiny ( $\varepsilon i \mu \alpha \rho \mu \varepsilon ́ v \eta)$. This is a classic case of

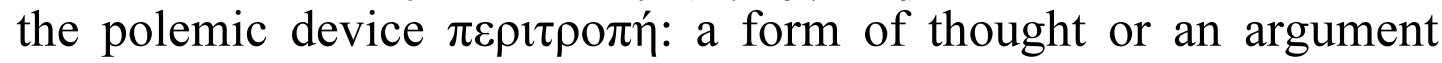
borrowed from an opponent is "turned around" and used against him like a boomerang. Researchers who conflated both concepts in single ill-defined category of "cosmic justice" overlooked the fundamental difference between the law of nature and natural law. Physicists do not deal with theories of natural law, political thinkers do not deal with laws of nature. Heraclitus was a moral and political thinker, not a physical scientist.

The lend-and-borrow or borrow-and-repay metaphorical code is directly attested in three authentic fragments of Heraclitus: fr. 31 Leb/B80 $\chi \rho \varepsilon \omega ́ \mu \varepsilon v \alpha$ "everything comes into being through strife and by borrowing (from the opposite)", fr.42Leb/B90 $\alpha v \tau \alpha \mu \varepsilon i \beta \varepsilon \sigma \theta \alpha \mathrm{l}$ (cf. vं $\pi \lambda \lambda \alpha \alpha$ a $\tau 0 v \sigma \alpha \nu$ "exchanging on the pledge of" in the context of

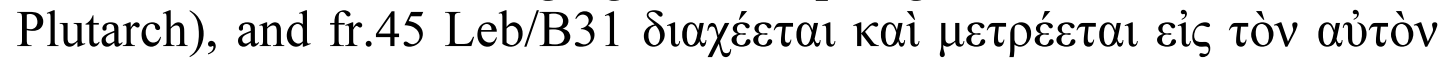
$\lambda$ óyov "the Sea is scattered and replenished by equal measure the

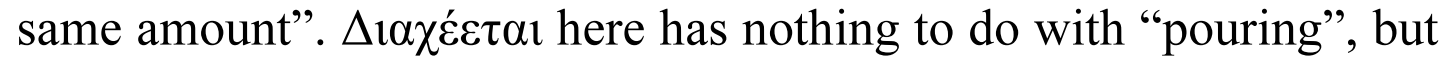
is used in the Homeric sense "to dismember, tear to pieces" (e.g. a

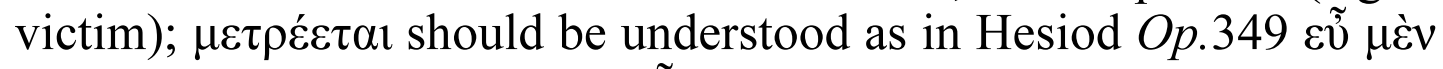

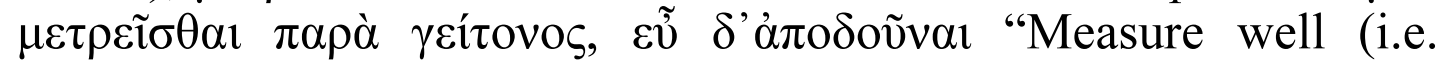
borrow) from neibhour and repay him well". Unlike modern commentators, Plutarch (De E, 393E) correctly renders archaic

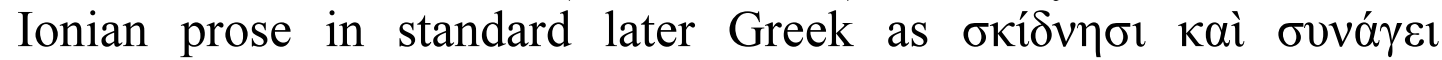
"scatters and collects". This is a universal formula of change from

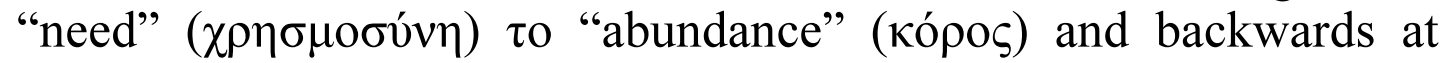
preset terms of fateful loan agreement. The borrow-and-repay cyclical change is also presupposed in the accusativus pretii $\zeta \tilde{\eta} 1$

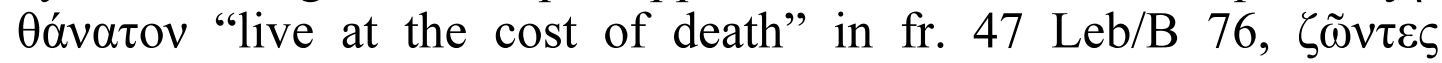

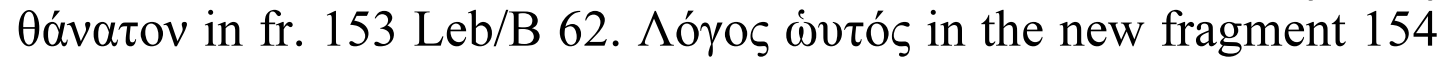
Leb, according to one interpretation, may refer to a "common account" or "common agreement" that binds mortals and immortals. Mortals are born when immortals (elements earth, water etc.) "die", i. e. are borrowed by human bodies, the death of mortals is the rebirth of immortals: earth to earth, water to water etc. 


\section{The game model of the cosmos: Lusoria Tabula}

The Greek game of pesseia itself is a model of war, with two 'armies' of game-pieces lined up against each other on a gameboard. Therefore, the game of the Time-god Aion in fr.33 Leb/B52 DK with the fate of the gods and humans is completely parallel to the cosmic war in the military model of the cosmos in fr. 32 Leb/B53.

The game-pieces change their positions on the opposite sides of the gameboard in the same way as the celestial and earthen beings (mortals and immortals), as well as souls (psychai), which travel on

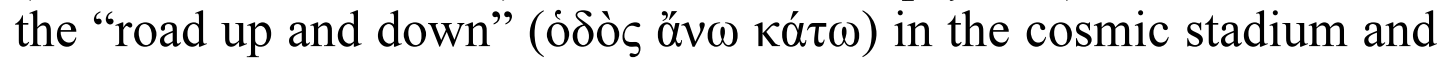
in the cosmic enantiodromia (fr.51A Leb). Aion and Polemos are exact metaphorical synonyms from two distinct metaphorical codes, with the same referential meaning of the Supreme being that governs the Universe, the new philosophical god of Heraclitus. Note that Hipolytus quotes the fragments on Aion and Polemos from the

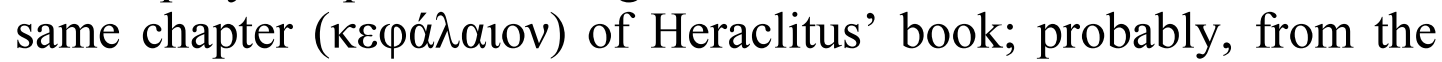
same context. The term "kingship" ( $\beta \alpha \sigma i \lambda \eta$ iो $)$ is ambivalent: it retains the political meaning of "kingship" similar to Polemos basileus in fr.32Leb/B53, but at the same time it alludes to the technical term basileus "king" in the game of pesseia that denotes prize-winning throw of dice or astragals with a numerical value of 30: for details see our commentary on this fragment. According to our hypothesis, two pairs of opposites from fr. 43 Leb/B67 $\pi$ ó $\lambda \varepsilon \mu o \varsigma$

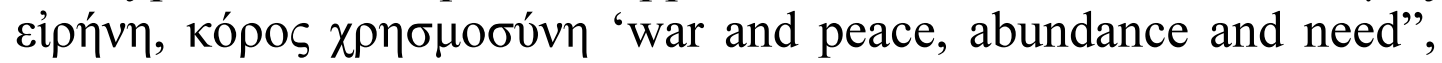
were symbolical names or meanings of the four sides, and of corresponding four throws, of an astragalos (knuckle-bone) in the Greek dice divination, astragalomanteia, a popular type of cleromancy, lot divination. The standard names of the four sides

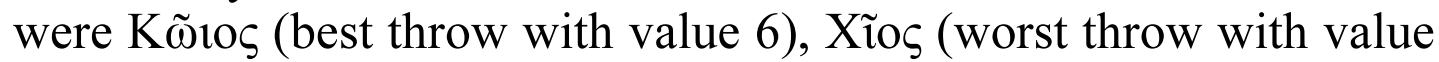
1), $\pi \rho \alpha v \varepsilon \dot{\varepsilon} \varsigma$ and $\check{\pi} \tau t \circ v$ with values 3 and 4 . Sides with values 5 and 2 existed only in a cube dice, not in an astragalos (for a helpful introduction to the topic see Nollé 2007: 7-10). The sum of the numerical values of the opposite sides is always 7, the sacred number of Apollo. Three out of the four names of the sides of an

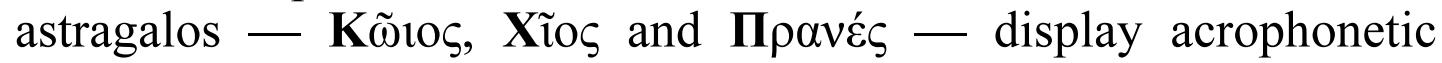

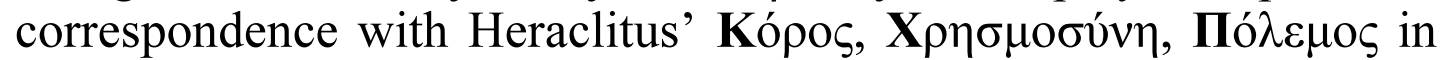
fr. $43 \mathrm{Leb} / \mathrm{B} 67$. "War or peace?", "Poverty or wealth?" were among the most often asked questions in popular divination. This

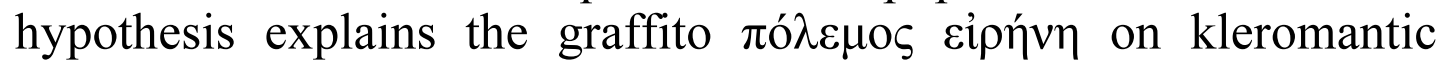
bone plates from Olbia, which we attribute to the "diviner of

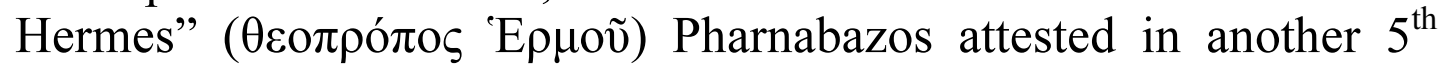


century B.C. graffito from Olbia. It is unlikely that this street fortuneteller at the end of the 5th century BC. had read the book of Heraclitus. It seems more probable that Pharnabazos and Heraclitus had a common source, the popular language of astragalomanteia. Traces of astragalos symbolism have been also seen in the word $\mu \varepsilon \tau \alpha \pi \varepsilon \sigma o ́ v \tau \alpha$ in fr. 76 Leb/ B 8 with the alleged meaning of "falling with another side up", although this is a common word for a sharp change (possibly, a dead metaphor from dicing), and it comes from a paraphrase. In the imitation of Lucian Vit. Auct. 14, $\pi \alpha i \bar{\zeta} \pi \alpha i \zeta \omega v$, $\sigma 0 \mu \varphi \varepsilon \rho \mu_{\mu \varepsilon v o \varsigma} \delta 1 \alpha \varphi \varepsilon \rho o ́ \mu \varepsilon v o \varsigma$ the last two words echo fr. 106Leb/B 10 , but in this context probably mean 'now winning' (bringing profit), now losing (causing devastation)', i.e. alternating wealth and poverty. On the relation between pesseia metaphors and hebdomadism see section 12 below.

\section{The sacral model of the cosmos: Templum Naturae}

Heraclitus introduces the concept of "ever-living fire" in Fr. 37Leb/B 30, in a style reminiscent of a pantheistic hymn to the cosmos, with a majestic triple "was, is and will be." The religious coloring of the fragment also corresponds to the sacred epithet

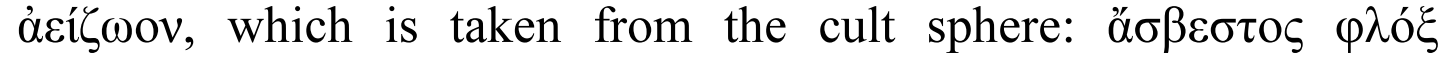
"inextinguishable flame", was sustained in a special hearth ( $\dot{\varepsilon} \sigma \chi \alpha \dot{\rho} \alpha)$ inside the temple, from which the external altar fire was ignited, as

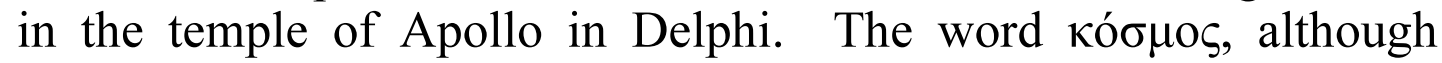
applied here to the Universe, has not yet completely lost its metaphorical character. In order to refer to the Universe, it still requires a deictic pronoun "this one" $\tau$ óv $\delta \varepsilon$, clarifying that the reference is not to some ordinary "decoration" or "ordered construction", but to the "construction" we all have before our eyes, that is, the visible world.

By saying that "this particular ordered construction" was not made by any god or man, Heraclitus implies that there are some

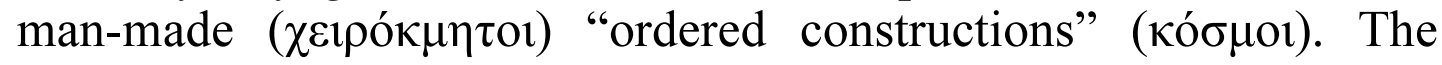
allusion is most probably to temples. A man-made temple is a house in which a cult statue of a god resides. "This cosmos" is a house in which lives not a cult statue of god, but a living god himself. We know that Heraclitus rejected adoration of marble statues as "madness" or "childish toys". The theoretical foundation of this rejection was his pantheism. All of these temple allusions in the text of the fragment suggest that the concept of divine fire in the philosophy of nature of Heraclitus is neither isolated nor comes 
from everyday life, but rather is, like 'this logos', a metaphor of an elaborate sacral metaphorical code that describes the world as a miraculous "not-wrought-by-hand" temple of nature. The idea and conceptual metaphor of the 'temple of nature' (Templum Naturae) is attested in the $4^{\text {th }}$ letter of Pseudo-Heraclitus (Ps.-Heraclit., Epist.

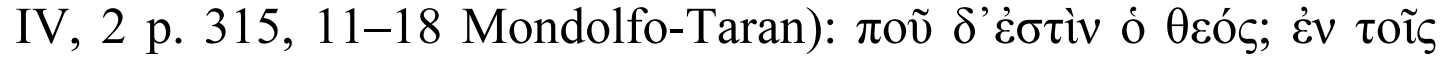

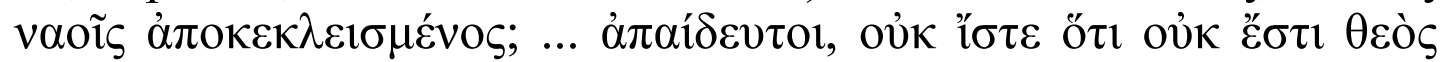

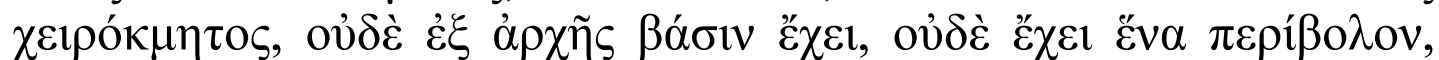

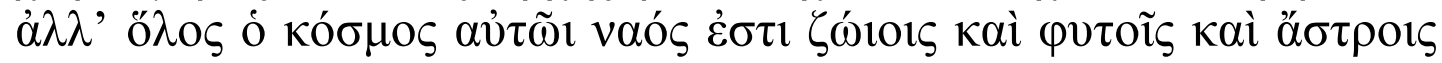

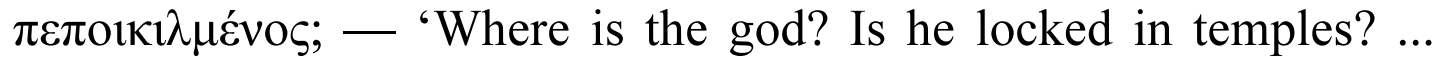
Ignoramuses! You do not know that God is not made by hands, that he does not have a pedestal, and that he is not enclosed in one fence, but the whole cosmos is a temple for him, decorated with living beings, plants and luminaries!'.

The fact that Heraclitus' concept of "ever-living fire" is inextricably linked with the Templum Naturae metaphorical model is further proved by the "incenses" metaphor in fragment 43Leb / B 67. Atmospheric phenomena (day and night, winter and summer) are compared in it with "incenses" burnt on a temple altar. These senseperceptible "incenses" are distinguished only by their deceptive subjective "smell" (ं்oví), but their imperceptible objective essence-substrate is one and the same, the ever-living fire ( $\pi \tilde{u} \rho$ $\dot{\alpha} \varepsilon i \zeta \omega o v)$. The word for incenses, $\theta v \omega \dot{\mu} \alpha \tau \alpha$ derives from the same root, as $\alpha v \alpha \theta v \mu i ́ \alpha \sigma i s$ 'exhalation', and both are etymologically cognate with Russian $\partial \mathrm{blm}_{\mathrm{m}}$ 'smoke', Latin fumus etc. Doxography ascribes to Heraclitus a theory of two exhalations, the light and dark one, which exactly correspond to the "day and night" of fragment 43 Leb/ B67. According to the common doxographical source of Placita and Diogenes Laertius, the light and dark exhalations in turn gather in certain "bowls" or "cavities" ( $\sigma \kappa \alpha ́ \varphi \alpha l)$ and so produce the alternation of day and night. This may be a later rationalistic interpretation of the original Heraclitean image of an altar with a cup-shaped cavity on the top. Here we can see how the doxographers extract from Heraclitus' poetic and theological discourse a "meteorological theory" that "explains" natural phenomena. One can argue about details, but in general terms it is possible with certain probability to reconstruct the basic image of the Templum naturae model: the space between heaven and earth is a kind of cosmic altar in the temple of nature, into which an invisible hand throws sensually perceptible "incenses": day and night, winter and summer, etc. 
The theological (monotheistic and pantheistic) message of this metaphorical construction is correctly explicated in the fourth pseudo-Heraclitean letter cited above. Only the fools (axynetoi) can worship the soulless stone idols locked in man-made temples. One should worship only the one true and living God, the Wise Being ( $\tau$ ò

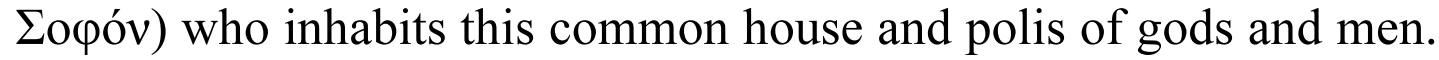
Sacrifice is the nourishment of God. The living god does not need

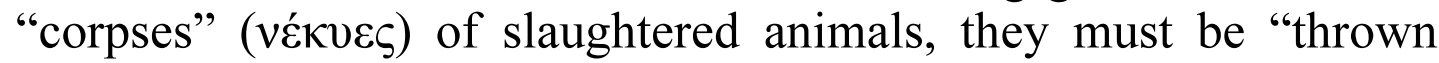
away sooner than dung" according to fr. $143 \mathrm{Leb} / \mathrm{B} 98$. The cosmic god feeds himself with evaporation (anathymiasis) from the sea, which daily rises to the cup of the sun.

Among the possible sources of this mythopoetic model of the cosmos, as well as parallels to it, one can cite architectural analogies in Anaximander's cosmology: the Earth has the shape of a drum of a stone column of a temple, and its diameter serves as a module for the frontal size of the temple (Lebedev 1980; Couprie 2011: 156157 ; see also Hahn 2001; 2010). In Philolaus' cosmology (44 A 16 DK), the Central Fire is compared to an altar ( $\beta \omega \mu$ ós), which suggests the comparison of the cosmos with a temple.

\section{The Biomorphic model: the cosmos as a living organism (isomorphism of macrocosm and microcosm)}

One should distinguish two types of the biomorphic model of the cosmos and biological analogies in cosmology in early Greek thought: a naturalistic and a teleological one. They differ because they are based on two different metaphysical paradigms, two different world-views. Biomorphic analogies can be both genetic, that is, modeling the origin and development of the cosmos, and structural-functional, that is, explaining the general structure and functioning of the cosmic organism. In the technomorphic model of the cosmos "matter", or "what all things are made of and consists of," is conceived as a passive "material" to be "molded" (by potter's craft), melted into different forms (by metallurgical craft), transformed by the craft of carpenter, like Aristotle's 0 $\lambda \eta$ which originally meant "wood" in a technomorphic analogy. On the contrary, in the biomorphic model of the cosmos the primary elements are understood as "seeds" (Anaximander's yóvuov, Anaxagoras $\sigma \pi \varepsilon \dot{\varepsilon} \mu \alpha \tau \alpha)$ or Empedocles $\dot{\rho}(\zeta \omega \mu \alpha \tau \alpha$, and the development of the cosmos is compared with "growth": For example, in the cosmogony of Anaximander, a "sphere of flame" is separated from the cosmic germ and "grows around the circumterrestrial air as a bark around a tree" (12 10 A DK). 
The "growth" of the organism, in turn, is understood as "nutrition" ( $\tau \rho о \varphi \eta$, $\tau \rho \varepsilon ́ \varphi \varepsilon \sigma \theta \alpha \imath)$, therefore the matter of the cosmos is understood as a kind of "food": in the Ionian tradition of Anaximander - Anaxagoras - Democritus (continued by Epicurus and Lucretius' semina rerum) matter is as panspermia, a mixture of various seeds $(\sigma \pi \varepsilon \dot{\varepsilon} \rho \mu \alpha \tau \alpha)$. This 'nutritional' and phyto-morphic concept of matter (= 'physis') is inextricably linked with Ionian evolutionism and stands in sharp contrast with predominantly technomorphic (creationist) concept of matter-material in Western thought followed by Plato and Aristotle. Another theory of cosmic "nutrition" (relating to everyday "nutrition" of the sun and the stars rather than to cosmogony) was the Ionian theory of "evaporation from the sea": in this case water or humid air was the cosmic "food". Aristotle ascribes to Thales the widespread Ionian theory that the sun and luminaries "feed" and live off "evaporation" (anathymiasis) from the sea ${ }^{19}$. The use of some biological (in particular embryological) analogies does not in itself speak of the general teleological character of a physical system. As a matter of fact, biological analogies are used, for example, in the cosmogony of Democritus, whereas the mechanistic determinism of Democritus and the atomists strictly excludes all teleology and divine providence ${ }^{20}$. Therefore, biomorphic analogies can be used in naturalistic (or mechanistic) physics, and in this case, we are talking about natural analogies (on this concept see introduction above). For example, the analogy between gray hair and withering of grass in Alcmaeon of Croton is a natural and not a metaphorical analogy, as it explains one observed natural phenomenon by analogy with another natural phenomenon ${ }^{21}$.

Only when biological analogies are systemic and combined with a pronounced isomorphism of micro- and macrocosm, as well as

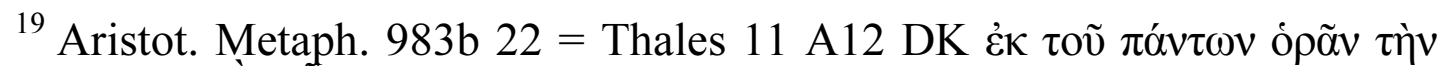

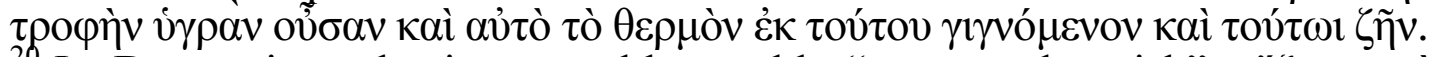

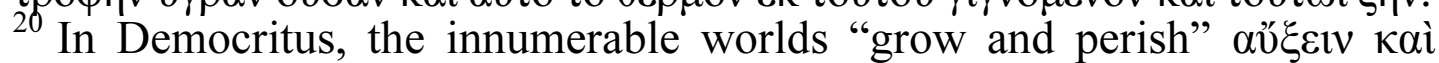
$\varphi$ Aíveıv Hippol, Ref. 1.12.2 = Democrit. fr. 291 Luria. - the terminology seems to be authentic, since in peripatetic doxography the standard terms

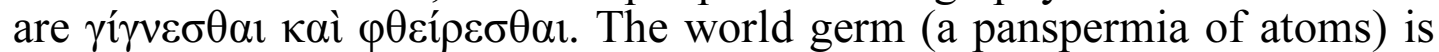
enclosed in a "shell" or "membrane" (iunvv), D.L.9.32 = Democrit. fr. 382 Luria. The term is taken from embryology, see LSJ. q.v. 1; Baldry 1932: 28. The term microcosm, $\mu$ Democritus.

${ }^{21}$ Arist. De gener. an.785a 25 sq. On this neglected fragment of Alcmaeon see Lebedev (2017) "Almaeon of Croton on human knowledge, the seasons of life and isonomia". 
pantheism and panpsychism (the concept of anima mundi, identified with the fundamental principle of the world), we are dealing with a teleological version of biomorphism akin to vitalism.

Mechanism is excluded in this model; it is an example of ethically relevant holism and organicism, usually in combination with a belief in divine providence and the theonomic ethics of the "following divine law". It is this version of pantheistic biomorphism (= panpsychism) that we find in Heraclitus and the Stoics; in the first century BC. it was synthesized with ancient Platonism and led to the emergence of "Stoic Platonism" (Bonazzi, Helmig 2007: passim). The parallelism of micro- and macrocosm in Anaximenes and Diogenes from Apollonia is more likely to be of a naturalistic (ethically irrelevant) type, although Heraclitus' teleological reinterpretation of Anaximenes' physics cannot be ruled out. We believe that two types of pantheism should be clearly distinguished in Greek thought: naturalistic pantheism (irreligious and ethically irrelevant) and ethical-religious pantheism. In the first case, God is reduced to nature, in the second, nature is reduced to God. The pantheism that Aristotle attributes to "the majority of physiologoi", is naturalistic ${ }^{22}$. "Nature" ( $\left.\varphi v ́ \sigma 1 \varsigma\right)$ or the fundamental principle of the cosmos is identified in it with "deity" ( $\tau$ ò $\theta \varepsilon \tilde{o} o v)$ only in the sense of being "immortal", that is eternal and indestructible in contrast to the "mortal" things, i. e. generated and destructible particulars. In most Ionian cosmogonies the world is produced by a cosmogonic vortex in the infinite ocean of matter. No Greek in his sound mind could ever believe that a cosmogonic vortex takes care of humanity or may be addressed in a prayer, or should be "followed" in practical life as a moral standard: Aristophanes points to the absurdity of this in the "Clouds". It was Heraclitus who subjected this naturalistic version of the pantheism to a polemical reinterpretation (peritrope $)^{23}$, that is, he transformed the naturalistic concept of "nature" as material substance of all things ( $\varphi v ́ \sigma ı)$ into theological and teleological concept by identifying nature with god. By making physis a teleological concept, Heraclitus anticipated Aristotle, while by making it a theological concept, he anticipated the Stoics. Ignoring the philosophical differences between these two types of pantheism

${ }^{22}$ Arist. Phys. 203b 6 sq. = Anaxim. A 15 DK. Contrary to Diels-Kranz, Aristotle speaks here not specifically about Anaximander, but about the "majority" of physiologoi, for more details see: Lebedev 1978: part 1. Cf. note 16 above.

${ }^{23}$ On the polemical device of peritrope in Greek philosophy see Lebedev (2019) "The authorship of the Derveni papyrus", p. 593-595. 
sometimes leads to serious misunderstandings, for example, to mistaken identification of the naturalistic monism of the Milesians with the ethical-religious monotheistic pantheism of the Orphic theogony. ${ }^{24}$ If there is indeed any connection between these two philosophies of nature, then it is exactly the reverse: that is, it is not the Milesians who depend on the so-called "Orphism", but the authors of Orphic theogony counterposed to the Ionian naturalistic cosmogony a creationist one.

According to reliable evidence of Aristotle, the author of the Orphic theogony was a diviner (chresmologos) at the court of Peisistratids in Athens, falsifier of oracles and adventurist Onomacritus. ${ }^{25}$ It may be assumed that considering the naturalism of the Milesians as a threat to traditional religion and morality, Onomacritus composed an alternative creationist account of the history of the world, in which the origin of the cosmos is explained not by the "eternal motion" of matter, but by the act of creation performed by the demiourgos Phanes (aka Erikepaios, Eros and Metis = Intelligence) ${ }^{26}$ In this version Onomacritus substitutes for Anaximander's "panspermia" of simple substances, the "sperm" of Phanes, which contains the "seeds" of all gods.

The reconstruction of the systemic parallelism of micro- and macrocosm in Heraclitus is based on three main testimonies:

The fragment 75Leb/B26 unequivocally draws a parallel

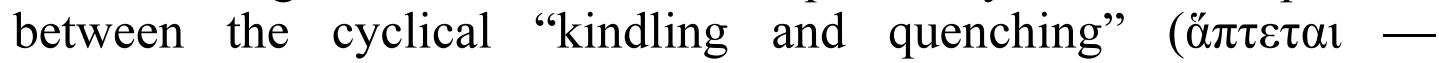
$\dot{\alpha} \pi 0 \sigma \beta \varepsilon ́ v v v \tau \alpha l)$ of the divine cosmic fire in Fr. $37 \mathrm{Leb} / \mathrm{B} 30$ and the alternation of light and darkness, sleeping and waking, life and death in man (óv $\theta \rho \omega \pi \circ \varsigma)$, conceived as microcosm.

According to the author of the Aristotelian Problems, the followers of Heraclitus recognize that "evaporation" from moisture occurs both "in the Universe" and in the human body, fr.69A (b)-(c) Leb. This refers to the evaporation from liquid food in the stomach, homologous to the sea in cosmos. Heraclitus' fragments quoted in Stoic sources (fr.67 Leb/B12 DK) speak of the evaporation of souls from the blood. Fragment $69 \mathrm{Leb} / \mathrm{B} 36$ apparently, is taken from the context of parallelism of the micro- and macrocosmic soul, as pluralis $\psi v \chi \tilde{\eta} 1 \sigma \mathrm{l}$ indicates. The author of "Problems" interpreted the transformation of souls into water within the body as physiology of

${ }^{24}$ Contra Finkelberg (1986) 325. On the confusion of two types of pantheism in the case of the Derveni papyrus see Lebedev (2019): 495-96.

${ }^{25}$ Philopon. In de anima p. 186, 24 = Aristot. De philosophia, fr. 7 Rose, cf. Orph. fr. 1109-1119 Bernabé.

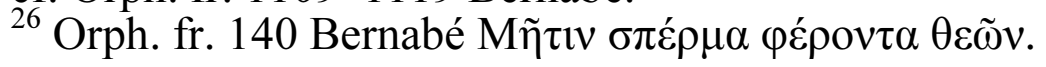


secretions, the formation of urine. If so, then the formation of "earth" inside the body should have corresponded to the formation of feces. However, such a straight physiological interpretation does not have clear parallels in other sources and is not found in the fragments of Heraclitus themselves. In other sources, and in the authentic fragments of Heraclitus, "moistening" of the soul is connected with psychology and ethics, as well as with cognition and sensuality (pleasure), but not with the physiology.

The Hippocratic imitation of Heraclitus in De diaeta, book 1, chapters 9-10 sets out a detailed doctrine of the isomorphism of the human body and the Universe.

The similarity between the structure and functioning of the human body on the one hand, and the cosmos on the other, is explained by the teleological operation of active and intelligent cosmic principle "fire" which constructed human body as "imitation

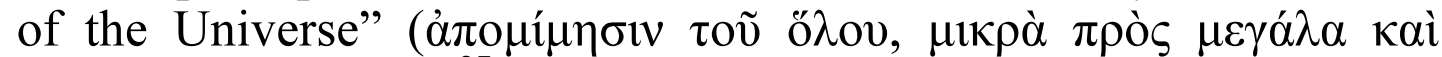

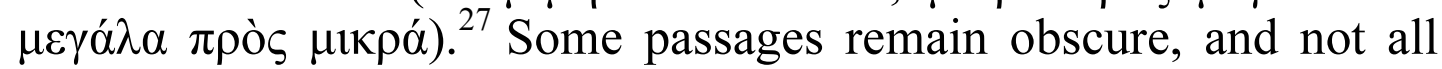
details can be attributed to Heraclitus. It is clear that the stomach is correlated with the sea, and the digestive tract with the earth. This first correlation system is supplemented by a second one on "three circuits (periodoi)" that the demiurgical fire created in the human body "in imitation of the Universe": the first circuit is localized "close to cavities with liquids" and corresponds to the Moon; the second, presumably, in the head and corresponds to the sphere of fixed stars; and finally the third, middle circuit in the region of the heart. This circuit corresponds to the Sun in the cosmos. "In it is the soul, mind, intelligence, movement, growth, decline, change, sleep, wakefulness, he always controls everything, and this and that, never stopping". The identification of the mind (and governing principle) of the cosmos with the Sun in Heraclitus is confirmed by fr. 69B Leb/B67a DK from Hisdosus) and fr.Probabilia 13 Leb. (Scythinus). The contrast between the pure solar region (heart and chest) and the impure region of the moon (abdomen) finds correspondence in the

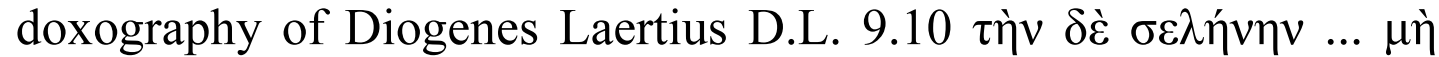

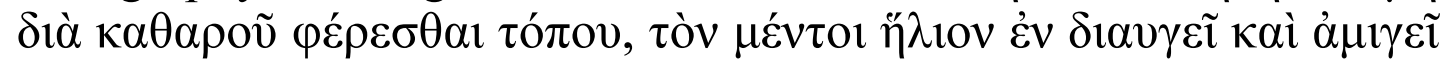
$\kappa \varepsilon \tilde{\sigma} \sigma \theta \alpha \kappa \tau \lambda$. 'The moon moves through impure region, while the sun is in a transparent and unmixed region etc.'.

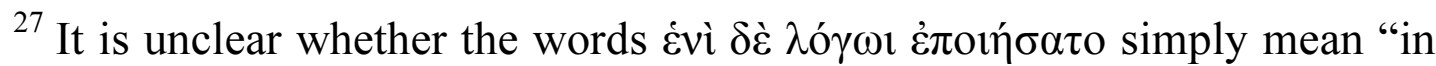
one word" or "by a single principle" (or "design"). In the latter case, we would have the only reminiscence of Heraclitus' concept of logos in De diaeta.
} 
The biomorphic model of the cosmos serves not only theological and eschatological, but also the ethical and political tasks of Heraclitus' work. Firstly, as with Marcus Aurelius, this holistic model emphasizes the need for cooperation and close interaction of citizens in the polis (on the often neglected 'workers' - ergatai and 'co-workers'- synergoi see our commentary on fr. 107 Leb/B75) in order to achieve a common goal, while also condemning pleonexia and individualism as contradicting nature. Men should "work together" as organs of a single body and follow the xynos logos, not their "private intelligence" and hedonistic desires. Secondly, humans do not occupy the best and purest place inside the body of the cosmic god. The best place is occupied by Apollo the Sun, in afterlife it is reserved only for the wise and heroes "slain by Ares" in the battle for freedom (they become commensals at the symposium of gods), whereas humans in earthly life are literally "buried in

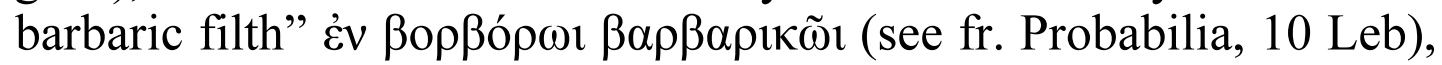
swarming around like worms in the "earth", that is, in the guts of the cosmic god.

This rhetoric was part of the military-patriotic exhortations of the liberation project of Heraclitus, it was addressed to the "snickering" Ephesian bourgeoisie and to all who trembled for their lives and did not want to fight against the Great king at the time or after the Ionian revolt. There is nothing to lose on this earth, the heroes will be awarded with a "better share" (Fr. 105 Leb/B25), their souls will fly to a much cleaner and more honorable places of residence in heaven in the company of the gods. "The souls of those who fell in battle are purer than those who died in disease" (Fr. 104 Leb/B136). Anonymus Iamblichi in 5.1 probably elaborates on this ethical topos of Heraclitus: he censures someone who 'spares his life' ( $\varphi \varepsilon 1 \delta o ́ \mu \varepsilon v o \varsigma \tau \tilde{\eta} \varsigma \psi v \chi \tilde{\eta} \varsigma)$ and suffers from excessive 'love of one's own life' ( $\varphi \imath \lambda \mathrm{o} \psi v \chi \chi_{i} \alpha$ is a vice!) because 'immortal glory' (apparently of a fallen hero) is more enviable than the evils of old age.

\section{Technomorphic (demiurgical) analogies: metallurgical, pottery, etc.}

There is no more erroneous and easily refutable stereotype in the history of early Greek philosophy than a view by which the concept of a demiurge or creator god was unknown or impossible before Plato $^{28}$. Indeed, in the early mythopoetic cosmogonies of the Greeks

${ }^{28}$ Recently, D. Sedley (2007) overcame this stereotype, recognizing as the first example of "rational creationism" the cosmogony of Anaxagoras. A 
(especially in Hesiod), dominant is the genealogical model of the origin of the world, and not a creation story. But this does not mean that the myths about the divine creation were unknown to the Greeks or represented - according to the pseudo-historical evolutionist scheme - a certain advanced stage of "development" to which the Greek mind allegedly had not yet ascended. Prometheus fashioned the first man from clay (and Athena breathed an intelligent soul into him) with the same ease with which the biblical god created Adam from the dust. Firstly, creation myths are much more ancient and archaic than the early Ionian physical theories of matter and vortexcosmogonies. Secondly, there is no reason to believe that Hesiod prefers the genealogical model because it is "more archaic" and creationism has not yet been "invented". Hesiod's "Theogony" is not a scientific logos; it is a hymn to Zeus and its goals are primarily religious, moral and didactic-educational, as well as poetical. The triumph of Zeus after defeating the forces of evil is also a triumph of Justice (Dike): all forms of legal and political life of mortals, as well as privileges of "kings" and distribution of honors ( $\tau \mu \alpha i)$, are based on the Justice of Zeus. Hesiod could well compose a story about how Zeus "made" heaven and earth, but firstly, this is not a royal occupation; for such works there is a blacksmith god Hephaestus.

And secondly, to derive the origin of Justice from the heroic victory in the great war over the forces of evil is much more meaningful and persuasive for the audience of Hesiod than to derive it from a technological process which is unworthy of Father and Kings of gods and men and as such, and has no relation with good and evil.

Already by the 6th century $\mathrm{BC}$ the cosmic demiourgos appears in Pherecydes' Pentemychos and in Orphic theogony. In the 5th century the Nus of Anaxagoras, and Love and Strife in Empedocles function as demiourgic (though not anthropomorphic) forces in cosmogony. We believe that the demiurge (identified with the mind) was also well known to the Pythagoreans: Philolaus compares the creator god with a ship builder who laid the central fire in the center of the Kosmos, just as the ship builder first laid the keel ${ }^{29}$. Thus, the demiurge of Plato was not an invention of the 4th century, but was a revival of ancient tradition, and Plato himself recognizes the

step in the right direction, but insufficient. Sedley ignores Heraclitus, the Pythagoreans and Philolaus.

${ }^{29}$ Stob. $1.21 .6 \mathrm{~b}=$ Philolaus A 17 DK. This testimony should be regarded as a "fragment" since the imagery is authentic. No doxographer could ever invent $a d$ hoc the unique image of ship builder. 
fabulous nature of this image, calling the entire cosmogony of Timaeus a "plausible fable" (cikò $\varsigma \mu \tilde{0} \theta$ os) $)^{30}$.

There are indications that the Milesians before Heraclitus used analogies from metallurgy and other industrial crafts, creating a new demythologized picture of the world. In Anaximander's cosmogony, the process of segregation of the initial mixture was compared with the washing of gold in a sieve; as a result of rotational motion, the gold particles and waste rock (earth) were separated ${ }^{31}$. In this case, an analogy was apparently implied between the rotational motion of the sieve and the cosmogonic vortex ( $\left.\delta i^{\prime} \eta\right)$. In explaining the nature of the sun Anaximander used an analogy from the blacksmith craft: the fiery "exhaust" from the wheel of the sun was compared with the

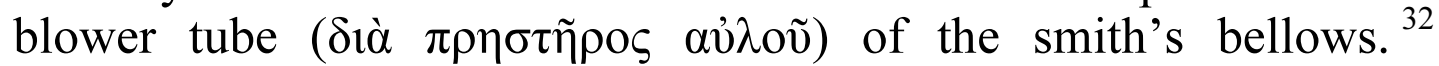
Anaximander explained the production of wind by the "melting" of air particles under the influence of solar heat (A 24). Anaximenes compared thickening of air into denser bodies with "felting" ( $\left.\pi^{i} \lambda \eta \sigma i \varsigma\right)$.

Miletus was one of the world centers for the production of woolen fabrics, and Anaximenes undoubtedly observed this process in workshops. The list of 20 different crafts $(\tau \varepsilon \dot{z} \chi v \alpha)$ in De diaeta 1. 10-24 is largely based on Heraclitean material (with revisions and additions) and aims to prove that "craft imitates nature" 33 . Of the "productive" crafts, that is, working with the material, three or four are attested also in sources independent from De diaeta: goldsmiths (fr. $116 \mathrm{Leb}$ ), iron craftsmen (f. 116A Leb), potters (f. $115 \mathrm{Leb}$ ), and, presumably, builders (114A Leb). For more details, see our commentary on these fragments.

It should be emphasized that, as in the case of biomorphic analogies, Heraclitus reinterprets them in a teleological vein, that is, gives them a meaning that was not intended by the Milesians. The

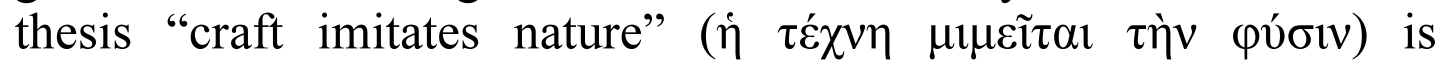
reversible: nature is a paradigm, a role model for human arts, and

\footnotetext{
${ }^{30}$ Plat. Tim. 29d, 68d.

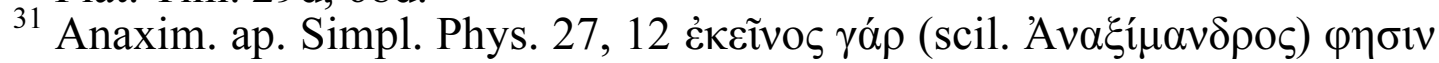

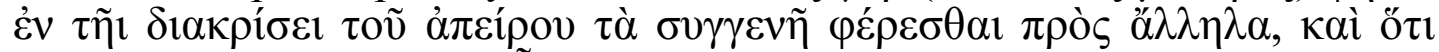

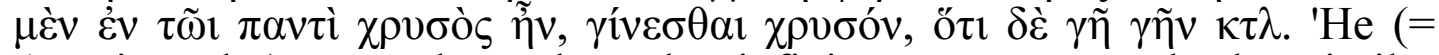
Anaximander) says that when the infinite was separated, the similar particles were carried towards each other, and that which was gold in the Universe, became gold, and that which was earth, became earth' (Lebedev 1988-1).

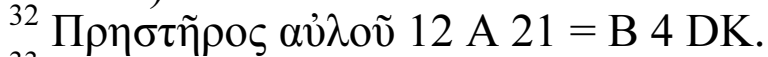

${ }^{33}$ For details see our commentary on fr. 106-124 Leb.
} 
therefore nature itself is an "craftsman" or "master" ( $\tau \varepsilon \chi v i ́ \tau \eta \varsigma)$. The neglected fragment of Heraclitus quoted in Aristotle's De Caelo draws an analogy between the cosmogonic process and the casting of various figures from the gold material (Fr.116 Leb). This proves that the Stoic concept of "fire-craftsman" ( $\pi \tilde{u} \rho \tau \varepsilon \chi v i \kappa o ́ v)$, if not verbally, then conceptually goes back to Heraclitus. Heraclitus' own sources, in turn, may have been both the observation of blacksmiths and gold workers in Ephesus, as well as the mythopoetic tradition linking the creative blacksmith god Hephaestus with fire.

\section{Sociomorphic (political) model: The Cosmopolis or the City of Zeus}

While engaging in a controversy with Homer about the benefits and harms of strife and war in the world of gods and men, as well as rejecting together with Homer's "pacifism" his anthropomorphism and polytheism in theology, Heraclitus at the same time breathed new life into the ancient military aristocratic ethics of "knightly honor" and heroic glory associated by Greeks with the Homeric "Iliad". He may have also found inspiration in the full of combatant spirit military-patriotic poems of his compatriot the poet Callinus of Ephesus.

Heraclitus may also have borrowed from Homer and the epic tradition and adapted to his purposes another important idea, that gods, like humans, are also organized and live in a community with Zeus as their "king". But since the traditional Homeric gods in Heraclitus' perception, under the influence of the Ionian enlightenment, lost their human shape and turned into luminaries and elements, from the synthesis of the Homeric 'community of the gods', on the one hand, and of Ionian cosmology, on the other, Heraclitus constructed the fundamental idea of his ethical and political philosophy, the idea of Cosmopolis or the City of Zeus (Zeus being identical with the cosmos and ever-living fire). The Cosmopolis binds together mortals and immortals by a shared

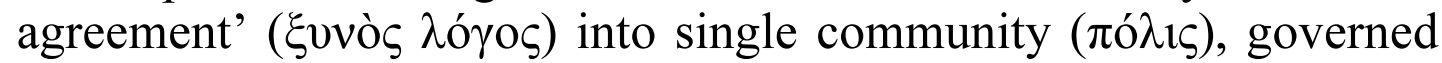

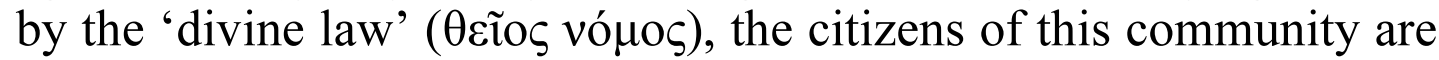
gods and men. But hoi polloi remain 'unfaithful' (ó $\pi 1 \sigma \tau o 1, \dot{\alpha} \pi 1 \sigma \tau i ́ \alpha$ fr.10 Leb/B19; $136 \mathrm{Leb} / \mathrm{B} 86$ ) to this law, they 'do not recognize it' like the 'dogs who bark at their master'(126 Leb/B97), they do not

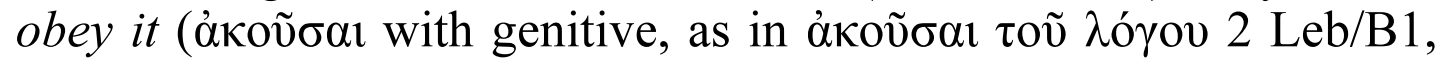
means 'to listen' in the sense of 'to obey'), because they do not

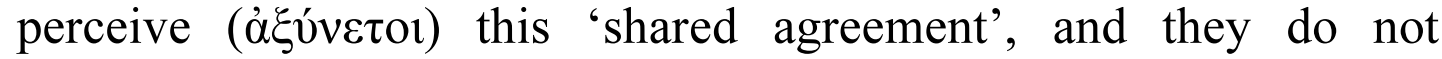
perceive it, because their souls are "barbaric" and "wet", that is 
unintelligent and immersed in Bacchic pleasures. This conceptual metaphor and political idea of Heraclitus had a tremendous impact on the Stoic concept of cosmos and Stoic doctrine of natural law, as well as on the cosmopolitanism of the Cynics, especially Antisthenes and the authors of Letters of Ps.-Heraclitus.

The idea of Cosmopolis is attested primarily in Heraclitus' own

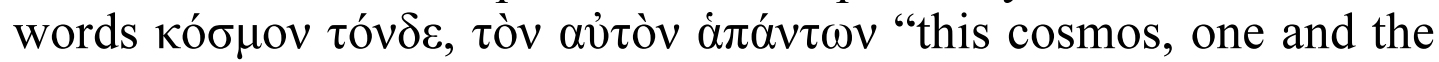
same for all beings", fr. 37 Leb/B30 DK.

It is clear from the context that by "all beings" ( $\dot{\alpha} \pi \alpha \dot{v} \tau \omega v)$

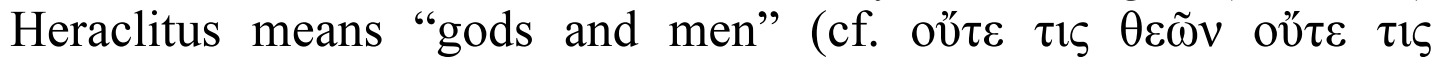
$\dot{\alpha} v \theta \rho \omega ́ \pi \omega \nu=$ oủ $\tau \iota \varsigma \dot{\alpha} \pi \alpha ́ v \tau \omega v)$, two broadest possible categories of living beings, the totality of which exhausts the entire content of the Universe. This prima facie archaic understanding of the world was borrowed from Heraclitus by the Stoics, who defined the concept of

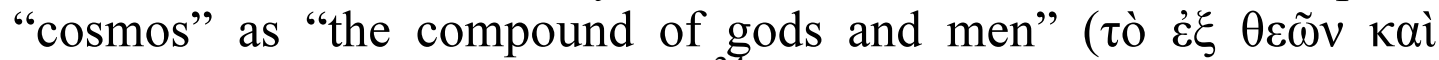

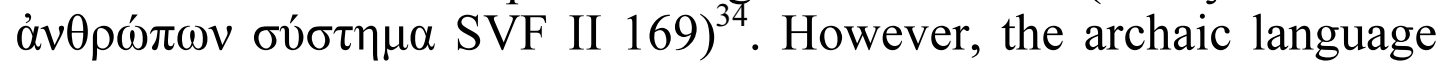
of Heraclitus can be deceiving, in this case we are dealing with a revolutionary idea that subverts the very foundations of Greek religion. The "communities" of the gods and men in Homer and in the traditional Greek beliefs are divided by an unbridgeable gap. Mortals by definition can never become immortal, of all mortals only one Heracles - due to his superhuman arete - managed to ascend to Olympus and become a member of the divine community. Heraclitus unites them into one common and 'shared' community, the gods and humans differ only in their temporary status (free and slaves, winners and losers), that can be reversed by personal effort,

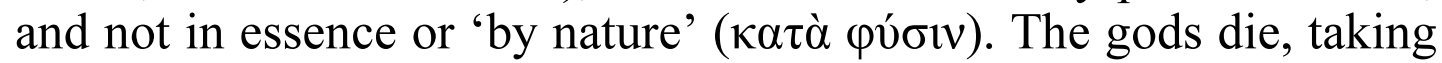
on the shape of mortal bodies, and elect humans ascend to heavens as a reward for their virtue and become the commensals of the gods.

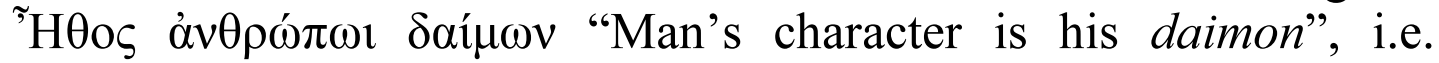
personal protector god who determines one's good (eudaimonia) or bad (kakodaimonia) fortune. One should 'hope for the hopeless'

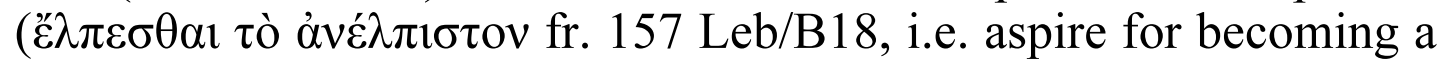
commensal of the gods. Exactly as later in the Stoic and Cynic philosophy, the wise in Heraclitus is first of all a citizen of the world, and only after this a citizen of the human polis. The author of Heraclitus' malicious biography in Diogenes Laertius book IX perfectly understood and parodied this idea of Heraclitus: refusing to "engage in the affairs of the community" ( $\pi$ o $\lambda \imath \tau \varepsilon v i \varepsilon \sigma \theta \alpha l)$ with

${ }^{34}$ On the idea if cosmopolis in Stoic philosophy see Schofield 1999: $57 \mathrm{ff}$.; Vogt 2008. 
corrupted Ephesians, Heraclitus leaves for the mountains and lives sub Jove frigido in the city Zeus, following the "divine law". He

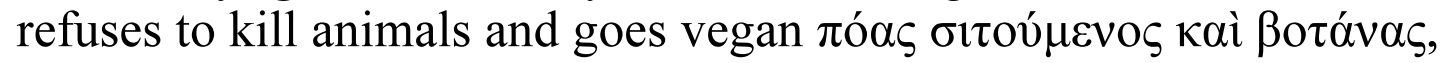
gets sick and self-medicates, practicing invented by him "cosmic medicine" which "imitates nature" by sustaining the balance of opposite powers. Dropsy is the predominance of the humid element, a metaphor of sensuality and hedonism that can be cured by ascetic "dryness".

Unlike biomorphic and technomorphic metaphorical codes, the sociomorphic code is absolutely unsuitable for the description of the genesis (birth or creation) of the cosmos, but is invaluable for someone whose goal is to describe the Universe in terms of hierarchical system, management and control. The concept of the "law of nature" is a faded metaphor of the sociomorphic metaphorical code, just as the concept of "matter" (hyle, materies) is a faded metaphor of a technomorphic code.

It is worth asking whether it is correct to speak about sociomorphic analogies or metaphors in Heraclitus. Heraclitus really believed that the visible cosmos is the polis of Zeus, inhabited by gods and humans who are bound by xynos logos and theios nomos. For him, it was not a metaphor, not an analogy, not a poetic image. One more caveat is necessary: although for the sake of clarity we have described the "economic" (lend-and-borrow) metaphorical code as a separate and independent code (it really has its own stable set of recognizable terms), in fact it is inextricably linked with the idea of Cosmopolis and the sociomorphic code, since it is primarily employed to explicate the operation of the "cosmic justice" and the underlying basic principle of "equal recompense" in a set term.

More can be found in the commentary on the principal text of Heraclitus about Cosmopolis and the "divine law", fragment 131Leb/B114. This text can be considered the first known formulation of the theory of natural law, and also - in the historical context of the Ionian revolt - an eloquent exhortation of exbasileus of Ionia to the Hellenes to unite in a "cosmic" super-state in order to defeat the Great king. This call of Heraclitus was heard and fully realized only by Alexander the Great, but we have advanced a hypothesis that his ideas may have influenced the founding fathers of the Delian League (Lebedev 2014: 20-21). 


\section{Hebdomadism in Heraclitus' philosophy of nature?}

The special significance of the number 7 in Greek popular arithmology and folklore is due to its connection with the cult of Apollo. Seven is the sacred number of Apollo, he was born on the 7 th day of the month of Thargelion. The collegium of molpoi, the priests of Apollo Delphinios in Miletus and Olbia consisted of 7 members.

The oracle of Apollo Didymeus from Olbia Pontica (beginning of the 5th century $\mathrm{BC}$ ) on a bone plate contains a prophecy with numbers $7,70,700,7000^{35}$. Both in the game of dice and in astragalomancy, ancient fortune telling based on dice, number seven plays important role, since in dice (both in classic cubes and in older four-sided astragals or knuckle-bones) the sum of the numerical values of the opposite faces is always seven: $1+6,3+4,5+2$. Astragals were found during excavations in the ancient layers of the temple of Artemis of Ephesus and the temples of Apollo in Asia Minor (Seipel 2008: 185, Nr 164; Nollé 2007: 10-17). The legend of the 7 sages is associated with the Delphi and the Pythian games in honor of Apollo (D.L. 1.27-29). Hebdomadism, an esoteric cosmological doctrine of the universality of the number seven in all spheres of being, is rather a marginal phenomenon in the early Greek philosophy of nature, but quite ancient. Hebdomadism is often combined with the doctrine of the parallelism of micro- and macrocosm, therefore it is not surprising that in medical circles it attracted the attention of the supporters of the "cosmological medicine", criticized in the Hippocratic treatise "On Ancient Medicine". There is no sufficient reason to postulate its oriental origin, since it has ancient roots in Greek folklore and the cult of Apollo. Solon, who in his elegy proposed a division of human life into ten hebdomads (fr. 27 West), did not know Accadian. A classic example of a cosmological-biological hebdomadism is the treatise "On the Hebdomads" in the Hippocratic corpus. Rocher considered it as the oldest prose treatise - a kind of incunabula, preserved in the library of the Kos School of Medicine (Roscher 1906: $44 \mathrm{ff}$.). Mansfeld came to the directly opposite conclusion that it was a product of Roman time, detecting the influence of Posidonius and the medical school of pneumatics (Mansfeld 1971: 229) ${ }^{36}$. In our opinion, such a late date should be ruled out.

\footnotetext{
${ }^{35}$ Editio princeps: Rusjaeva, VDI (1986) Nr.2, 25-64.

${ }^{36}$ Mansfeld's date is 60-30 BC., between Posidonius and Varro. In order to be able to distinguish the specific vitalism of Posidonius from, say, the
} 
The text contains archaic elements, for example, the preclassical use of the word кó concentric spheres of the same cosmos. Such a usage is attested only for Anaximander, that is, it points to the 6th century (Kerschensteiner 1962: 29). In any case, the treatise should not be dated later than the middle of the 5th century BC., since probable traces of acquaintance with him are found in the treatise "On Diet", which we date approx. 430-420 BC.

In authentic verbatim fragments-quotations from Heraclitus we do not find explicit Hebdomadism, we do not find any mention of numbers at all, and this is consistent with his hostility to Pythagoras. There are only two exceptions: fragments $60 \mathrm{Leb}$ and $64 \mathrm{Leb} / \mathrm{B} 126 \mathrm{a}$. In the new Oxyrrhynchus fragment on the phases of the moon 60 Leb it is said in section (b) that when the crescent appears on the third day after the new moon, it becomes full moon in 14 days. But the authorship of Heraclitus does not seem indisputable to us, and some doubts are especially raised by the (b) section (see our commentary to this fragment). The astronomical fragment of Anatolius on the seven stars of Arktos in "On the Decade" (Fr. 64 Leb/B126A DK) is undoubtedly hebdomadist. Its language and style do not look as suspicious as those of the Oxyrrhynchus fragment. The author of this text definitely strives to 'demonstrate' the divine and universal-cosmic nature of the number 7 , arguing that the count of days according to the moon in months, and the count of months in a year is somehow determined by the number 7. Evidence on Heraclitus' interest in chronological numbers in general, and in hebdomads of human life in particular, can be found in the complex of doxographical reports relating to the human "generation" (genea) as 30 years, defined as "the time in which a man can become a grandfather" and derived from duplicating the cycle of maturity plus one year of pregnancy: $(14+1) \cdot 2=30$ (fr.71 Leb, cf. A 19 DK). There are also two divergent doxographical reports on the duration of the Great Year (Megas Eniautos) in Heraclitus: 10800 years according to Censorinus' De die natali, 1800 years according to Stobaeus (see fr. 63Leb = A13 DK). Censorinus' figure 10800 has

panpsychism of Heraclitus, the animistic conception of elements in Empedocles, or from the doctrines "everything is full of gods" or "the soul is mixed in the Universe" (which Aristotle attributes to Thales, who lived 500 years before Posidonius) one needs a special gift of discernment. The author of these lines does not possess such a gift and therefore considers the vitalism of Posidonius as an ancient Stoic heritage dating back to Heraclitus. 
been explained as the duration of human generation (30 years) multiplied by the supposed number of days in the "Great year" (360), on the assumption that human "generation" (genea) constitutes one day in the Great year, the lifespan of cosmic god. The only possible trace of hebdomadism in all this is the age of maturity (14):

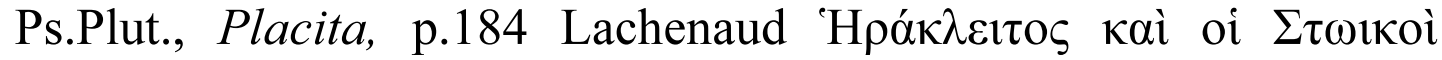

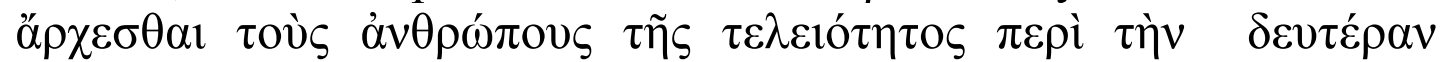

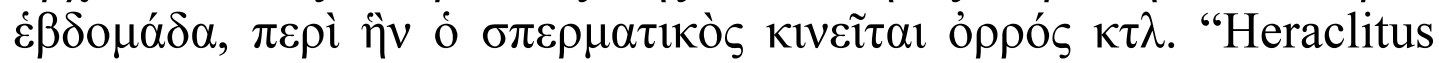
and the Stoics hold that men attain maturity at the second hebdomad when the seminal liquid starts to be ejaculated...". Heraclitus' supposed hebdomadism would be in perfect agreement with the theme of Apollo's wisdom, a leitmotif of his book, and the dominant role of Apollo in Heraclitus' cosmotheism: the "signs" ( $\sigma \eta \mu \alpha i v \varepsilon \imath)$ of the Lord of Delphi are everywhere. Hebdomadism is often an integral part of the isomorphism of micro- and macrocosm, and so would be for Heraclitus a welcome confirmation of the latter. All extant Heraclitus' fragments and testimonia with possible relation to hebdomads, concern the importance of the number 7 in biological cycles on the one hand, and in astronomical cycles, on the other, that is, establish a mirror correspondence and parallelism between the earthly and heavenly, and thus the dependence of the human world on the divine, which was one of the main theses of Heraclitus' book.

Assuming the authenticity of the doxographical tradition on the hebdomadic structure of the human generation in the anthropology and psychology of Heraclitus, one might regard the relevant texts as

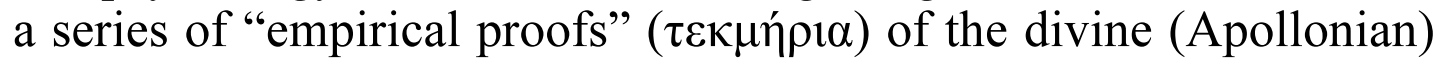
origin of the human soul, or rather of its noblest part, the intellect (vóos, $\varphi \rho \eta ́ v, \gamma \nu \omega ́ \mu \eta)$. In terms of the Heraclitean physics of elements, the sensory soul is an "exhalation" (anathymiasis) from the blood, while the intellect (noos), presumably, corresponds to the purest solar fire in macrocosm. Apollo is allegorically identified by Heraclitus with the sun.

The skeptic would make the following objections to this optimistic reconstruction. First, the authenticity of fragments $60 \mathrm{Leb}$ and $64 \mathrm{Leb} / \mathrm{B} 126 \mathrm{~A}$ remains controversial. We cannot rule out the possibility that these fragments derive not from the authentic book of Heraclitus, but from a heraclitizing Neopythagorean astronomical treatise on hebdomads of Imperial times. Just as some Hippocratic doctors were attracted by Heraclitus' idea of the isomorphism of micro- and macrocosm that provided them with a theoretical basis of a "cosmology-based" medicine, therapy, and diet "according to nature", so Pythagorizing astrologers of Imperial times could be 
attracted by Heraclitus' doctrine of the periodic conflagration (ecpyrosis), which they connected with the recurrent configurations of the planets and the theory of eternal return. An example of such astrological reception of Heraclitus' genuine doctrine of ecpyrosis is

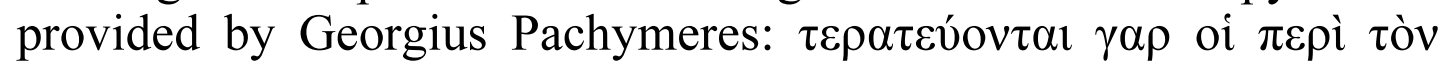

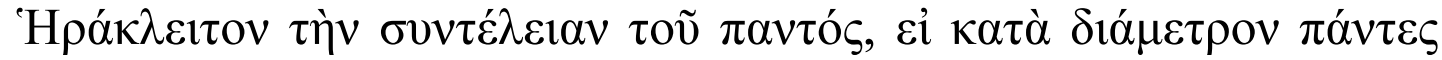

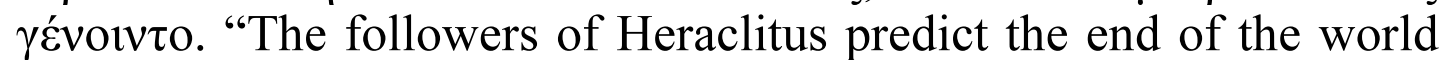
when all planets will line up in diameter". ${ }^{37}$ Another warning is provided by the text which Diels mistakenly included in his collection of genuine fragments of Heraclitus, B105DK: certain "Heraclitus" regarded Homer "astrologist" on the ground of his interpretation of Homeric verse $\Sigma 251^{38}$. In Heraclitus' time

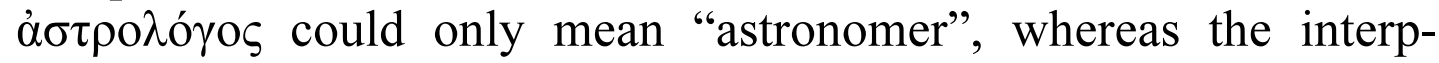
retation of Homeric verses at issue is astrological. This Heraclitus lived in Roman times, he was either the well-known grammarian (Allegorist) or an astronomer, a representative of the learned Homerolatria of Roman times, that saw in Homer's wisdom the source of all philosophy and sciences, including astronomy and astrology. Against the authenticity of Heraclitus quotation in

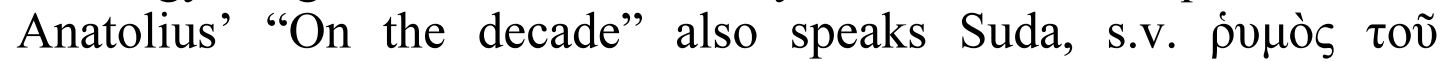

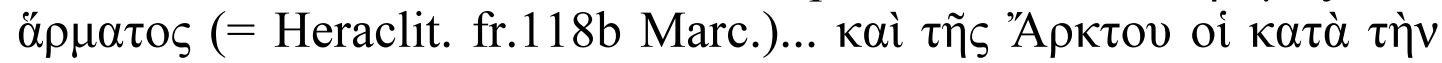

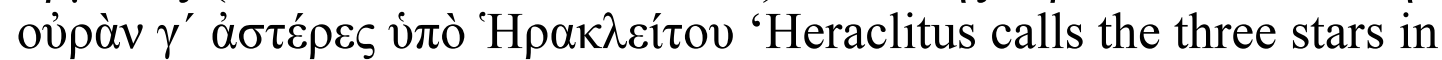
the tail of the Great Bear 'Cart tax'. It is hard to imagine Heraclitus of Ephesus counting the stars in the tail of Ursa Major; for him this

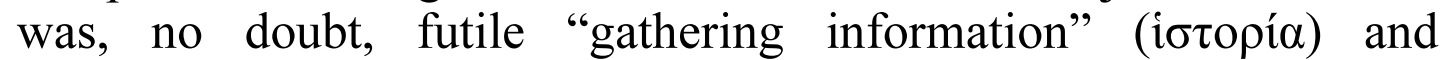
polymathia. Meanwhile, the quotation in Suda and the quotation on Arktoi in Anatolius cannot be separated: both are concerned with the number of stars in Ursa Maior, both derive from the same common source and therefore stand or fall together.

As for the doxographic numbers for the "generation" ( $\gamma \varepsilon v \varepsilon \alpha$ )

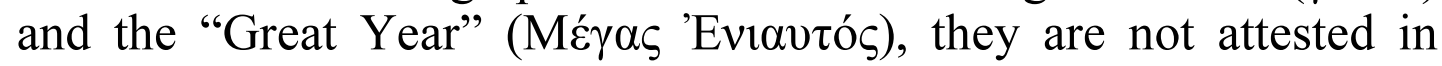
verbatim quotations, neither the numbers nor the words $\gamma \varepsilon v \varepsilon \alpha ́$ and

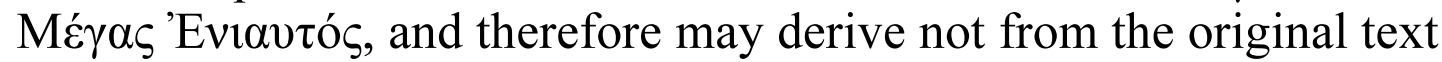
of Heraclitus, but from exegetical literature, from numerous ancient commentaries whose authors competed in solving the "riddles" of the "Obscure" philosopher. Hebdomadism and the number 30 may have been reconstructed by Heraclitus' commentators from the

\footnotetext{
${ }^{37}$ Georg. Pachymer. Quadrivium: astronomia 14, p. 385, 22 Stephanou $=$ Heraclit. fr. 118 (d) Marc.

${ }^{38}$ We include this text in "Dubia et spuria", see Nr. 1 with our commentary. Contra Marcovich, ad fr. 63ab.
} 


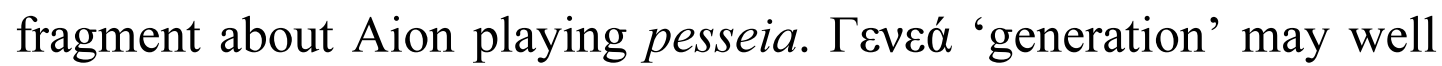
be commentator's rendering of the original aióv in the sense of 'man's life' or 'lifespan'. Note that in Censorinus, De die nat. 17,2 (= Heraclit. fr. $108 \mathrm{~b} 2$ Marc.) vocat orbem aetatis (scil. genean) may

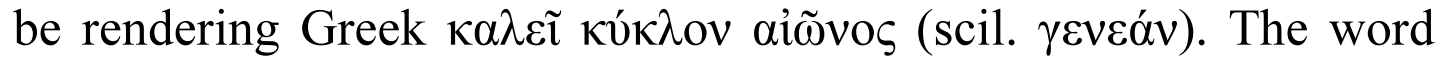
$\pi \varepsilon \sigma \sigma o i ́$ could denote not only game-pieces in a backgammon-type boardgame, but also knuckle-bones for dicing; the author of Heraclitus' vita in Diogenes took $\pi \varepsilon \sigma \sigma \varepsilon v ́ \omega v$ in this way $(\dot{\alpha} \sigma \tau \rho \alpha \gamma \alpha \lambda i \zeta \omega v)$. The best throw of four dice was called 'king' $\beta \alpha \sigma i \lambda \varepsilon v ́ s$, its prize value was 30 (see our commentary on fr.33Leb/B52 for details). Taking aív in the sense of 'man's life' (rather than of long time or eternity) and the mention of 'kingship' as a cryptic allusion to number 30 , the commentators 'reconstructed' Heraclitus' doctrine of 'generation' as 30 years. The artificial character of such theory is obvious: very few, if any, Greeks could become grandfathers at the age of 30, and $\gamma \varepsilon v \varepsilon \alpha ́$ in Greek language never refers to the combined lifespan of two generations. The numbers for the 'Great year' were obtained by multiplying the human 'generation' 30 by 360 , the supposed number of days in the Great year. The discrepancy in the numbers of the Great year (10800 in Censorinus and 18000 in Placita) may be explained not as a corruption of the original 'correct' number in transmission, but as a discrepancy between two divergent calculations. The optimist (who believes in hebdomadism in Heraclitus) may try to counter this pessimistic conclusion. He may object that even if there was no explicit mention of number 30 in Heraclitus' text, and even if it was explicated by commentators, this explication may well be correct:

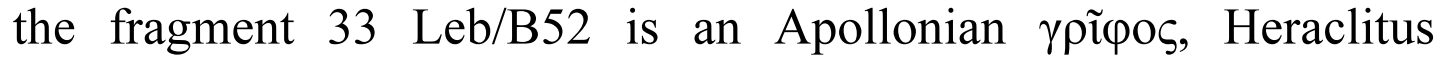
himself "encrypted" in it a hebdomadic message through the symbol of Apollonian astragalomancy, which indeed is based on the sacred number seven. It is not easy to answer the question if the fr. $33 \mathrm{Leb} / \mathrm{B} 52$ indeed alludes to numbers seven and thirty, or this is a conjecture of ancient commentators, only Heraclitus himself could answer this question with certainty. The same uncertainty remains in the case of the image of cosmic lyre of Apollo in Scythinus of Teos: does it contain an allusion to seven strings and Apollonian number seven? In our opinion, fr.33 Leb/B52 can be satisfactorily interpreted without reference to numbers associated with astragalomancy. It is largely "parallel" to the fragment about Polemos with which it is quoted by Hippolytus from the same context of Heraclitus' book. Both fragments speak about the Supreme Being, the 'king' of the Universe, the new philosophical god of Heraclius. 
Both contain the 'triadic structure' of Heraclitus' metaphysics and theology $(2+1)$, but express it in two different metaphorical codes, the military and the game code. Hebdomadism is certainly present only in Fr.64 Leb/B126A, and possibly in the Oxyrrhynchus fragment on the phases of the moon $(60 \mathrm{Leb})$, but how reliable are these sources? We leave the question of hebdomadism in Heraclitus open, although we do not exclude that cosmic symbolism of number seven may have played some role in the 'mantic' metaphorical code as elaboration on the theme of Apollo's wisdom and as one of the

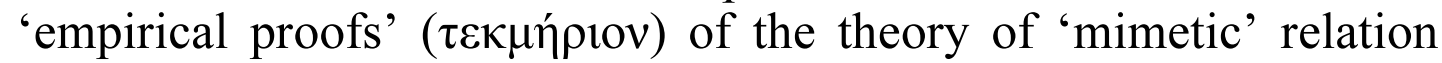
between heaven and earth, which the Stoics later transformed into their doctrine of cosmic sympatheia. This uncertainty about hebdomadism should not cast any doubt on the reconstruction of the game (pesseia) metaphorical code above (section 7). That the symbolical names of the alternating periods of 'Megas Eniautos' in fr. 43

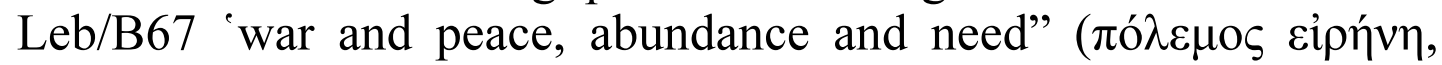

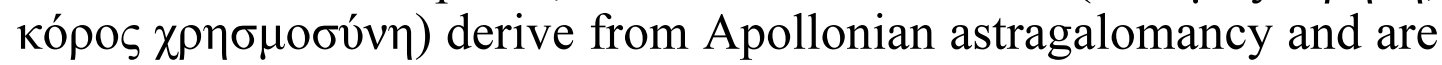
connected with the imagery of playing $(\pi \varepsilon \sigma \sigma \varepsilon v ́ \omega v)$ divine child Aion in fr.33Leb/B52, seems to us certain. This is confirmed by the

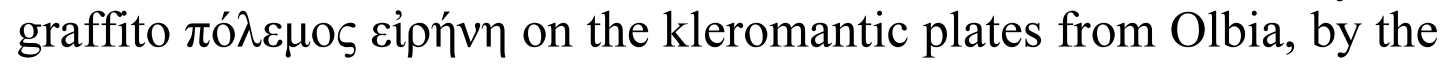
acrophonetic correspondence noticed above, and by Heraclitus' speech in Lucian, Vit.auct.14, in which the 'pesseia' of Aion refers to the alternation $(\dot{\alpha} \mu \varepsilon ı \beta o ́ \mu \varepsilon v \alpha)$ of gain and loss, wealth and poverty:

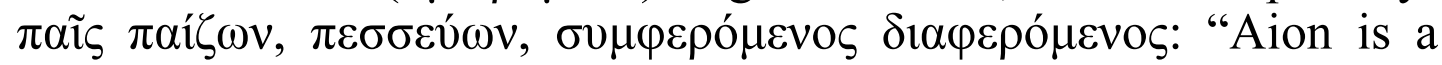
child playing pessoi, now bringing profit, now devastation".

\section{Bibliography}

Barnes, J. 1979: The Presocratic Philosophers. Vol. 1-2. Routledge \& Kegan Paul.

Bonazzi, M., Helmig, Ch. (edd.) 2007: Platonic Stoicism - Stoic Platonism. The Dialogue between Platonism and Stoicism in Antiquity. Leuven University Press.

Couprie, D. 2011: Heaven and Earth un Acient Greek Cosmology. From Thales to Heraclides Ponticus. New York.

Diels, H., Kranz, W. 1951: Die Fragmente der Vorsokratiker, Griechisch und Deutsch von Hermann Diels. Herausgegeben von Walter Kranz. Erster Band. Berlin: Weidmann, 139-190 (6th edition).

Conche, M. (ed.) 1986: Héraclite. Fragments. Texte établi, traduit, commenté par Marcel Conche, Paris (PUF).

Finkelberg A. 1986: On the Unity of Orphic and Milesian Thought. The Harvard Theological Review. 79 (4), 321-335.

Hahn, R. 2001: Anaximander and the Architects. Albany, NY.

Kahn, Ch. 1979: The Art and Thought of Heraclitus. An Edition of the Fragments with Translation and Commentary. Cambridge: CUP. 
Kazansky, N. N. 2010: On the prehistory of the state - ship metaphor in Greek culture. In: Vs. E. Bagno (ed.). Russian Fate of Winged words. St. Petersburg, 2010. P. 77-95. (in Russian).

Казанский, Н. Н. 2010: К предыстории метафоры «государствокорабль» в греческой культуре. В сб.: Багно В. Е. (отв. ред.). Русская судьба крылатых слов. СПб.: «Наука». С. 77-95.

Kerschensteiner, J. 1962: Kosmos: Quellenkritische Untersuchungen zu vorsokratischen Philosophie. München (= Zetemeta 30).

Kirk, G. S. 1954 (1970): Heraclitus. The Cosmic Fragments. Edited with an Introduction and Commentary by G. S. K. Cambridge: Cambridge UP.

Lakoff, G., Johnson, M. 1980: Metaphors We Live By. Chicago UP.

Lebedev, A. V. 1979: ПАТНP - $\triangle$ НМIOҮРГО $\Sigma-$ ВА I $\Lambda Е Y \Sigma$. The Synonymity of metaphorical codes in ancient Greek cosmogonical texts. In: BALCANO-BALTO-SLAVICA, = Symposium on the structure of text, ed. by V. V. Ivanov, Institute of Slavic and Balcanic Studies of the Russian Academy of Sciences, Moscow, 24-29. (in Russian).

Лебедев, А. В. 1979: ПАТНР Синонимия метафорических кодов в древнегреческих космогонических текстах. В кн.: BALCANO-BALTO-SLAVICA. Симпозиум по структуре текста. Под ред. Вяч. Вс. Иванова. М.: Ин-т славяноведения и балканистики АН. 1979, 24-29.

Lebedev, A. V. 1980: Geometric style and Anaximandros' cosmogony. In: Culture and Art of Ancient World. Proceedings of the conference held in Pushkin's Museum of fine Arts. Moscow, 100-124. (in Russian).

Лебедев, А. В. 1980: Геометрический стиль и космология Анаксимандра. В сб.: Культура и искусство античного мира. Материаль научной конференции ГМИИ им. А. С. Пушкина. М., 100-124.

Lebedev, A. V. 1985: The Cosmos as a Stadium: Agonistic Metaphors in Heralitus' Cosmology. Phronesis 30 (2), 131-150.

Lebedev, A. V. 1988: The Imagery of Lampadedromia in Heraclitus. ФІ $\Lambda$ О $\Sigma$ ОФІА. 1987-1988. Vol. 17-18, 233-257.

Lebedev 2014: The Logos of Heraclitus: A Reconstruction of his Word and Thought (With a New Critical Edition of the Fragments). St. Petersburg. (in Russian).

Лебедев, А. В. 2014: Логос Гераклита: реконструкиия мысли и слова с новым критическим изданием фрагментов. СПб.

Lebedev, A. V. 2017: The Metaphor of Liber Naturae and the Alphabet Analogy in Heraclitus' Logos Fragments (With some remarks on Plato's "dream theory" and the origin of the concept of elements). In: E. Fantino, U. Muss, Ch. Schubert, K. Sier (Hrsg.), Heraklit im Kontext. Walter de Gruyter: Berlin; New York, 231-267. (= Studia Praesocratica v.8)

Lebedev, A. V. 2017²: Parmenides the Pythagorean: Monistic Idealism (Mentalism) in Archaic Greek Metaphysics. Indo-European linguistics and classical philology 22 (2), 493-536.

Lebedev, A. 2017 : Alcmaeon of Croton on Human Knowledge, the Seasons of Life and ISONOMIA: A New Reading of B 1 DK and 
Two Additional Fragments from Turba Philosophorum and Aristotle. In: Ch.Vassallo (ed.). Physiologia. Topics in Presocratic Philosophy and Its Reception in Antiquity. Trier: Wissenschaftlicher Verlag, 227-257. (= AKAN-Einzelschriften, 12)

Lebedev, A. 2017 ${ }^{4}$ : Epicharmus on God as Mind (NOOS). A Neglected Fragment in Stobaeus. (With some remarks on early Pythagorean metaphysics and theology). In: Artisteas. Vol. XVI, 13-27.

Lebedev, A. V. 2019: The Authorship of the Derveni Papyrus, A Sophistic Treatise on the Origin of Religion and Language: A Case for Prodicus of Ceos. In: Presocratics and Papyrological Tradition. A Philosophical Reappraisal of the Sources. Proceedings of the International Workshop held at the University of Trier (22-24 September 2016). Edited by Christian Vassallo. Berlin; Boston, 491-606.

Lebedev, A. V. 2019²: Idealism (Mentalism) in Early Greek Metaphysics and philosophical theology: Pythagoras, Parmenides, Heraclitus, Xenophanes and others (with some remarks on the "Gigantomachia over being» in Plato's Sophist). Indo-European Linguistics and Classical Philology 23, 651-704.

Lloyd, G. E. R. 1966: Polarity and Analogy. Two Types of Argumentation in Early Greek Thought. Cambridge UP.

Lloyd, G. E. R. 1987: The Revolutions of Wisdom. Cambridge UP.

Marcovich, M. (ed.) 1967: Heraclitus. Editio maior. Merida, Venezuela.

Marcovich, M. (ed.) 1978: Eraclito. Frammenti, a cura di Miroslav Marcovich. Firenze.

Mondolfo, R., Taran, L. 1972: Eraclito. Testimonianze e imitazioni, Introduzione, traduzione e commento a cura di Rodolfo Mondolfo e Leonardo Tarán. Firenze.

Mansfeld, J. 1971: The Pseudo-Hippocratic Tract ПЕPI EB $\Delta \mathrm{OMA} \Delta \Omega \mathrm{N}$ and Greek Philosophy. Assen.

Nollé, J. 2007: Kleinasiatische Losorakel. Astragal- und Alphabetchesmologien der hochkaizerzeitlichen Orakelrenaissance, München.

Roscher, W. 1906: Die Hebdomadenlehre der griechischen Philosophen und Ärzte. Leipzig: Teubner.

Schofield, M. 1999: The Stoic Idea of the City. Chicago; London.

Sedley, D. 2007: Creationism and its Critics in Antiquity. Berkeley; Los Angeles.

Seipel, W. (Hrsg.) 2008: Das Artemision von Ephesos. Heiliger Platz einer Göttin. Wien.

Snell, B. 1926: Die Sprache Heraklits. In: Hermes, 61. Bd., H. 4 (Oct., 1926), 353-381.

Vogt, K. M. 2008: Law, Reason and Cosmic City. Political Philosophy in the Early Stoa. Oxford UP.

Zaicev, A. I. 2001: Cultural Revolution in Ancient Greece $8^{\text {th }}-5^{\text {th }}$ Cent. BC. St. Petersburg, (in Russian)

Зайцев, А. И. 2001: Культурный переворот в Древней Греции VIII-V вв. до н. э. 2-ое изд. СПб. 